This PDF is a selection from a published volume from the National Bureau of Economic Research

Volume Title: Measuring Economic Sustainability and Progress

Volume Author/Editor: Dale W. Jorgenson, J. Steven Landefeld, and Paul Schreyer, editors

Volume Publisher: University of Chicago Press

Volume ISBN: 0-226-12133-X (cloth); 978-0-226-12133-8

(cloth); 978-0-226-12147-5 (eISBN)

Volume URL: http://www.nber.org/books/jorg12-1

Conference Date: August 6-8, 2012

Publication Date: September 2014

Chapter Title: Measuring Social Welfare in the U.S. National Accounts

Chapter Author(s): Dale W. Jorgenson, Daniel T. Slesnick

Chapter URL: http://www.nber.org/chapters/c12825

Chapter pages in book: (p. $43-88)$ 


\title{
Measuring Social Welfare in the US National Accounts
}

\author{
Dale W. Jorgenson and Daniel T. Slesnick
}

\subsection{Introduction}

At the meeting of the Conference on Research in Income and Wealth in April 2004, D. Jorgenson, J. Steven Landefeld, William D. Nordhaus, and their coauthors proposed a new architecture for the US national accounts. ${ }^{1}$ The initial step in implementing the new architecture was the integrated macroeconomic accounts for the United States, developed by the Bureau of Economic Analysis (BEA) and the Board of Governors of the Federal Reserve System (FRB). ${ }^{2}$ In this chapter we employ the integrated macroeconomic accounts as the starting point for measuring social welfare. ${ }^{3}$

Our measure of potential social welfare is based on personal consumption expenditures. Actual social welfare depends on the distribution of consumption over the population, and we refer to this as the standard of living. Our measure of inequality is the difference between potential and actual social

Dale W. Jorgenson is the Samuel W. Morris University Professor in the Department of Economics at Harvard University. Daniel T. Slesnick is professor of economics at the University of Texas at Austin.

We are indebted to J. Steven Landefeld, Lawrence J. Lau, and Thomas M. Stoker for their collaboration on earlier phases of this research. Thanks are due to Jon D. Samuels for his excellent work on the national accounts and helpful comments. Finally, we are indebted to Dennis Fixler and Timothy Smeeding for their comments on an earlier draft. Financial support by the Donald B. Marron Fund for Research at Harvard University is gratefully acknowledged. The usual disclaimer applies. For acknowledgments, sources of research support, and disclosure of the authors' material financial relationships, if any, please see http://www.nber.org/chapters /c12825.ack.

1. Jorgenson, Landefeld, and Nordhaus (2006).

2. Teplin et al. (2006). For current data from the integrated macroeconomic accounts, see http://www.bea.gov/national/nipaweb/Ni_FedBeaSna/Index.asp.

3. Plans for developing these accounts are discussed by Cagetti et al., chapter 10, this volume. 
welfare. ${ }^{4}$ Our measures of the cost and standard of living and inequality are consistent with the integrated macroeconomic accounts and the US National Income and Product Accounts (NIPAs). ${ }^{5}$

In September 2009, Joseph E. Stiglitz, Amartya K. Sen, and Jean-Paul Fitoussi presented the "Report by the Commission on the Measurement of Economic Performance and Social Progress" to the former president of France Nicolas Sarkozy. ${ }^{6}$ The report called for a shift in the focus of economic measurement from production toward "people's well-being." The report contained twelve specific recommendations, including the use of consumption, income, and wealth, rather than production, for this purpose. $^{7}$

The recommendations of the Stiglitz-Sen-Fitoussi Commission's report are complementary to those of the nearly contemporaneous 2008 System of National Accounts (United Nations 2009), which includes consumption, income, and wealth. ${ }^{8}$ In response to the Stiglitz-Sen-Fitoussi Commission's report, the Organisation for Economic Co-operation and Development (OECD) has established an international expert group chaired by the Australian Bureau of Statistics to develop new international standards and guidelines for microeconomic data on income, consumption, and wealth. ${ }^{9}$ The OECD has established a second international expert group on disparities in the national accounts chaired by Eurostat to consider the role of distributional statistics in the national accounts. ${ }^{10}$

The new architecture for the US national accounts avoids confusion between production and welfare, a key concern of the Stiglitz-Sen-Fitoussi Commission's report. By augmenting personal consumption with its distribution over the population, we are able to incorporate detailed measures of the cost and standard of living and inequality into the NIPAs. ${ }^{11}$ By including production, as measured by the gross domestic product (GDP) and gross domestic income (GDI), we can also include measures of output, input, and

4. For more details see Jorgenson (1990) and Slesnick (1998).

5. See Jorgenson (1997b) and Slenick (2001).

6. Stiglitz, Sen, and Fitoussi (2010). For more detail on the commission and its reports, see http://www.stiglitz-sen-fitoussi.fr/en/index.htm. For a discussion of the implications of the Stiglitz-Sen-Fitoussi Commission's report for the NIPAs, see Landefeld et al. (2010).

7. A more technical presentation of issues in the measurement of welfare or "social wellbeing" is given in Fleurbaey (2009). This is partly based on Fleurbaey's report to the commission. For more details, see http://www.stiglitz-sen-fitoussi.fr/documents/Individual_Well-Being _and_Social_Welfare.pdf. Fleurbaey's own proposal for welfare measurement is presented in Fleurbaey and Maniquet (2011).

8. United Nations (2009).

9. $\operatorname{OECD}(2013 \mathrm{a}, \mathrm{b})$.

10. Fesseau, Wolff, and Mattonetti (2013) and Fesseau and Mattonetti (2013).

11. The measurement of household income in the United States is discussed by Harris (chapter 7, this volume). The measurement of household wealth in the United States is discussed by Henriques and Hsu (chapter 9, this volume). The integration of household consumption and income data into the US national accounts is discussed by Fixler and Johnson (chapter 8, this volume) and McCully (chapter 6, this volume). 
productivity in the national accounts, as pointed out in chapters 19 and 20 of the 2008 SNA.

In section 3.2 we introduce measures of individual and social welfare within the new architecture for the US national accounts. The key feature of our measures of individual welfare is that they are cardinal and interpersonally comparable. We aggregate these measures by means of a social welfare function. In section 3.3 we employ individual and social expenditure functions to provide money measures of individual and social welfare appropriate for the national accounts.

Our measures of individual welfare incorporate three types of information. We use personal consumption to represent the size of the household budget. We express the household's consumption in constant prices. We then divide real consumption by household size. Finally, we express individual welfare as the logarithm of real consumption per capita, so that increments of individual welfare are equal to proportional increases in consumption. These features are commonly employed in the literature on consumer behavior.

We combine measures of individual welfare into a measure of social welfare. We emphasize that the validity of social welfare evaluations depends on the normative conditions of horizontal and vertical equity, as well as information on consumer preferences. We consider a class of social welfare functions that combines the mean of individual welfare with a measure of dispersion that gives additional weight to equity considerations.

In section 3.4 we present the empirical counterparts of individual and social expenditure functions, exploiting an econometric model of aggregate consumer behavior described in greater detail in the appendix. In section 3.5 we summarize the new architecture and update the key accounting magnitudes for consumption and production presented by Jorgenson (2009). ${ }^{12} \mathrm{We}$ link our measure of welfare to personal consumption expenditures and our measure of production to the GDP.

In section 3.6 we present measures of the cost and standard of living and inequality within the US national accounts. We incorporate distributional information into the measurement of inequality and the standard of living. The Consumer Price Index (CPI) produced by Bureau of Labor Statistics (BLS) can be interpreted as a measure of the cost of living. The Bureau of the Census generates official statistics on the standard of living, poverty, and inequality. However, these statistics are not integrated with the NIPAs.

While our welfare measures are consistent with the 2008 SNA and the proposals of the Stiglitz-Sen-Fitoussi Commission's report, we emphasize links to the NIPAs and the integrated macroeconomic accounts for the United States. In section 3.7 we discuss possible extensions of the national accounts to include nonmarket activities. Examples are household production and 
consumption, the accumulation of human capital, the enhancement of environmental quality, and health care.

We conclude by recommending that national statistical agencies experiment with the incorporation of measures of social welfare into the national accounts. The availability of properly constructed welfare measures would address concerns about the misuse of the GDP as a measure of welfare. However, there is little justification for treating welfare measures as a substitute for income, consumption, wealth, or other economic aggregates that appear in the national accounts.

\subsection{Measuring Individual and Social Welfare}

Despite the exclusion of social welfare from the national accounts, welfare measurement is well established in both economic theory and economic statistics. ${ }^{13}$ Sen's (1970) magisterial Collective Choice and Social Welfare was a crucial turning point in the theory of social choice. ${ }^{14}$ Sen greatly broadened the scope of welfare measurements by mapping out the alternatives to the traditional assumptions of ordinal measures of individual welfare that are not comparable among individuals. This led to an explosion of research on "possibility theorems" during the following decade. ${ }^{15}$ For example, measures of inequality based on social welfare functions by Anthony B. Atkinson and Serge C. Kolm were given a rigorous foundation in the theory of social choice summarized by Roberts (1980). ${ }^{16}$

Following the elaboration of new conceptual possibilities for welfare measurement, we developed an econometric methodology to eliminate the gap between the theory of social choice and measures of welfare used in economic statistics. This gap arises from the fact that surveys of consumer expenditures are based on households rather than individuals, a distinction almost absent from the theoretical literature. We presented the results in a series of papers on the cost and standard of living, inequality, and poverty. ${ }^{17}$ Our approach to welfare measurement is summarized in Jorgenson's (1990) presidential address to the Econometric Society, Slesnick's (1998) survey article in the Journal of Economic Literature, and Slesnick's (2001) book.

Econometric models of consumer behavior have long been used in measuring individual welfare. ${ }^{18}$ The challenge we faced was to extend this approach to social welfare by comparing levels of welfare among individuals and aggregating over them. Our solution to this problem was to exploit the

13. The measurement of social welfare is discussed by Jorgenson (1997b) and Slesnick (2001). 14. Sen (1970).

15. For a summary of this literature and many new results, including the framework used for our social welfare measures, see Roberts (1980). Fleurbaey and Maniquet (2011) have proposed an approach to welfare measurement that retains the traditional assumptions.

16. See Atkinson (1970) and Kolm (1969).

17. These papers are collected in Dale W. Jorgenson (1997b).

18. See Deaton and Muellbauer (1980, ch. 9, 214-40) and Slesnick (1998). 
econometric model of aggregate demand introduced by Jorgenson, Lawrence Lau, and Thomas Stoker (1982). ${ }^{19}$

Aggregation over individuals is obviously the key to social welfare measurement. It is straightforward to incorporate the restrictions on individual consumer behavior required for aggregation. The necessary framework is provided by the theory of household behavior of Gary S. Becker, Pollak, and Paul A. Samuelson. ${ }^{20}$ However, this is beyond the scope of the traditional theory of consumer behavior based on individuals.

Jorgenson, Lau, and Stoker showed how to recover the models of individual demand that underlie their model of aggregate demand. In Jorgenson and Slesnick $(1983,1984)$ we derived cardinal measures of individual welfare that are interpersonally comparable from these models of individual demand. We introduced the normative assumptions employed by Roberts (1980) and aggregated our measures of individual welfare by means of a social welfare function.

Our final step was to convert individual and social welfare into money measures appropriate for the national accounts, using the individual expenditure function introduced by Lionel McKenzie (1957) and the social expenditure function originated by Robert Pollak (1981). ${ }^{21}$ We used these tools in developing a "dashboard" of detailed measures of social welfare, later recommended by Stiglitz, Sen, and Fitoussi (2010). We also developed measures of welfare for groups within the population and showed how to aggregate them into overall measures of social welfare.

Our empirical research used observations on households from the Consumer Expenditure Survey (CEX), conducted by BLS on a quarterly basis since $1980 .{ }^{22}$ An important feature of the CEX, like other consumer expenditure surveys, is that observations are available for households, but not for individuals. To generate interpersonal comparisons based on households, we employed a long-established concept in economic statistics, household equivalence scales. ${ }^{23}$

The concept of household equivalence scales has been used to establish family needs for income support programs and assess the cost of additional children. We derived household equivalence scales econometrically from household expenditure functions. ${ }^{24}$ These household equivalence scales, like traditional scales, depend on the demographic characteristics of households.

19. Jorgenson, Lau, and Stoker (1982). This paper is included in Jorgenson (1997a, 203-359).

20. See Becker (1981), Pollak (1981), and Samuelson (1956).

21. McKenzie (1957) and Pollak (1981).

22. In 2009 the BLS launched the Gemini Project to improve the quality of data reported on the survey. For details on important limitations of the current CEX, see http://www.bls.gov/cex /geminiproject.htm.

23. See Jorgenson and Slesnick (1987). This paper is included in Dale W. Jorgenson (1997b). Alternative approaches to household equivalence scales are summarized by Slesnick (2001, 88-121) and OECD (2013a, 152-57).

24. This approach to modeling household behavior was originated by Barten (1964). 
Unlike traditional scales, our household equivalence scales also depend on prices faced by households.

The introduction of household equivalence scales into the measurement of social welfare bridged the gap between the economic theory and economic statistics. The conceptual basis for this link was established by Arthur Lewbel (1989) in a paper on the economic theory of household equivalence scales. ${ }^{25}$ Lewbel began by clarifying the role of exact aggregation in deriving cardinal measures of individual welfare that are interpersonally comparable.

Lewbel demonstrated that household equivalence scales can be identified under the assumptions that these scales are independent of household welfare, depending only on household characteristics and prices. These are precisely the assumptions employed in our household equivalence scales. Using the possibility theorems summarized by Roberts (1980), Lewbel combined these household equivalence scales with cardinal measures of individual welfare, using our approach as a key illustration.

Our cardinal and interpersonally comparable measures of household welfare fit neatly into the framework of the theory of social choice. This has provided a rigorous approach to measuring social welfare that successfully exploits econometric methods for modeling consumer behavior. However, official measures of the cost and standard of living and inequality in the United States have been unaffected by these econometric methods. ${ }^{26}$

\subsection{Money Measures of Individual and Social Welfare}

In this section we assume that household expenditures are allocated to maximize a household welfare function. As demonstrated by Samuelson (1956) and Pollak (1981), the household behaves in the same way as an individual maximizing a utility function. We treat households as individuals in measuring social welfare. All subsequent references to individuals are to households considered as consuming units.

We present money measures of individual and social welfare. Our measures of individual welfare are based on the preference orderings of consumers. We represent these orderings by real-valued individual welfare functions. Our measure of social welfare is based on preferences over social states by all individuals. We represent a social ordering by means of a real-valued social welfare function, defined on the distribution of individual welfare over the population.

To provide a money measure of individual welfare, we represent prefer-

25. Lewbel (1989). For more details, see Fleurbaey and Hammond (2004).

26. Recommendations for revisions of the official measures have been provided by Jorgenson (1990) and Slesnick (2001). Supplemental measures of poverty based on income have been proposed by the Bureau of the Census (2011). See http://www.census.gov/hhes/povmeas/. These are based on a 1995 report by the National Academy of Sciences. See Citro and Michael (1995). 
ences by means of an individual expenditure function, using the following notation:

$p_{n}$ : price of the $n$th commodity, assumed to be the same for all consuming units.

$p=\left(p_{1}, p_{2}, \ldots, p_{N}\right)$ : vector of prices of all commodities.

$x_{n k}$ : quantity of the $n$th commodity consumed by the $k$ th consuming unit $(n=1,2, \ldots, N ; k=1,2, \ldots, K)$.

$x_{k}=\left(x_{1 k}, x_{2 k}, \ldots, x_{N k}\right)$ : vector of quantities of all commodities consumed by the $k$ th consuming unit $(k=1,2, \ldots, K)$.

$M_{k}=\sum_{n=1}^{N} p_{n} x_{n k}:$ total expenditure of the $k$ th consuming unit $(k=1,2, \ldots, K)$. $A_{k}$ : vector of attributes of the $k$ th consuming unit $(k=1,2, \ldots, K)$.

The individual expenditure function gives the minimum total expenditure $M_{k}$ required for the $k$ th consuming unit to achieve the welfare level $W_{k}$ at the prices $p(k=1,2, \ldots, K)$. More formally, the individual expenditure function $M_{k}\left(p, W_{k}, A_{k}\right)$ is defined by:

$$
M_{k}\left(p, W_{k}, A_{k}\right)=\min \left\{M_{k}=\sum_{n=1}^{N} p_{n} x_{n k}: W_{k}\left(x_{k}, A_{k}\right) \geq W_{k}\right\} .
$$

Individual welfare $W_{k}$ is the maximum attainable at total expenditure $M_{k}$. This is a money measure of individual welfare at the current price system $p$.

We employ the individual welfare function and the individual expenditure function to construct measures of the standard of living and its cost. We illustrate these concepts geometrically in figure 3.1. This represents the indifference map for a consuming unit with expenditure function $M_{k}\left(p, W_{k}, A_{k}\right)$. For simplicity we consider the case of two commodities $(N=2)$. Consumer equilibrium in the base period is represented by the point $A$. The corresponding level of individual expenditure $M_{k}\left(p^{0}, W_{k}^{0}, A_{k}\right)$, divided by the price of the second commodity $p_{2}^{0}$, is given on the vertical axis. This provides a representation of individual expenditure in terms of units of the second commodity.

Consumer equilibrium in the current period is represented by the point $C$. To translate welfare $W_{k}^{1}$ into total expenditure at the prices of the base period, we evaluate the individual expenditure function (1) at this level of welfare and the base period price system $p^{0}$. The resulting total expenditure $M_{k}\left(p^{0}, W_{k}^{1}, A_{k}\right)$ corresponds to consumer equilibrium at the point $B$. The ratio between levels of total expenditure $M_{k}\left(p^{0}, W_{k}^{1}, A_{k}\right)$ and $M_{k}^{0}$ is the household standard of living. The price index given by the ratio between levels of total expenditure $M_{k}^{1}$ and $M_{k}\left(p^{0}, W_{k}^{1}, A_{k}\right)$ is the household cost of living.

Under the Pareto principle, a social state represents an improvement over an alternative state if all consuming units are as well off as under the alternative, and at least one unit is better off. The Pareto principle provides a partial ordering of social states. This ordering is invariant with respect to monotone increasing transformations of individual welfare that differ among consuming units. Only welfare comparisons that are ordinal and noncomparable among consuming units are required. 


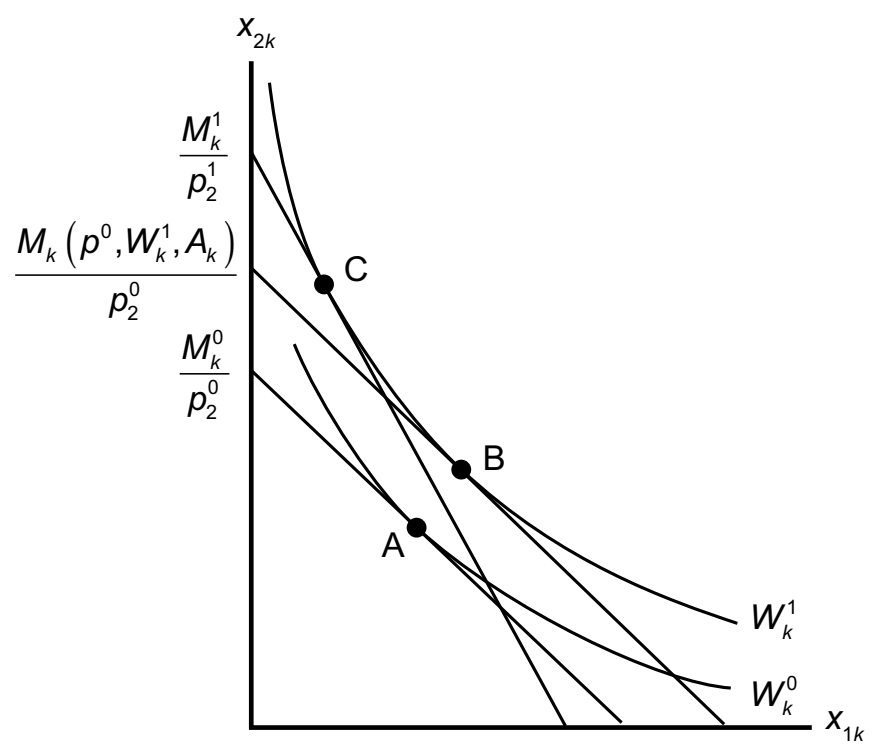

Fig. 3.1 Household standard of living and its cost

The money measure of individual welfare provided by the expenditure function (1) is a monotone increasing transformation of individual welfare. This transformation depends on the prices faced by the consuming unit and on attributes of the consumer. Considered as a measure of individual welfare in its own right, this measure provides the information about preferences required for applications of the Pareto principle. To obtain a complete ordering of social states we next introduce a social welfare function.

We consider orderings over the set of social states and the set of realvalued individual welfare functions. To describe these social orderings in greater detail we introduce the following notation:

$x$ : matrix with $N x K$ elements $\left\{x_{n k}\right\}$ describing the social state.

$u=\left(W_{1}, W_{2}, \ldots, W_{K}\right)$ : vector of individual welfare functions of all $K$ consuming units.

To represent social orderings in a form suitable for measuring social welfare we consider a class of social welfare functions $W(u, x)$ incorporating a notion of horizontal equity. We require that individuals with identical individual welfare functions enter the social welfare functions in the same way. We also incorporate a notion of vertical equity by requiring that the social welfare functions are equity-regarding in the sense of Hammond (1977). This imposes a version of Dalton's (1920) principle of transfers: A transfer from a household with a higher welfare level to a household with a lower 
welfare level that does not reverse their relative positions must increase the level of social welfare. ${ }^{27}$

To provide a money measure of individual welfare, we have expressed individual welfare in terms of total expenditure. Similarly, we can express social welfare in terms of aggregate expenditure. For this purpose we introduce the social expenditure function, defined as the minimum level of total expenditure, $M=\sum_{k=1}^{K} M_{k}$, required to attain a given level of social welfare, say $W$, at a specified price system $p$. More formally, the social expenditure function $M(p, W)$ is defined by

$$
M(p, W)=\min \left\{M=\sum_{k=1}^{K} M_{k}: W(u, x) \geq W\right\} .
$$

For a given price system we translate social welfare into monetary terms by evaluating the social expenditure function. To determine the level of social welfare we first evaluate the individual welfare functions $\left\{W_{k}\right\}$ for all consuming units at the price system $p$ and the distribution of total expenditure $\left\{M_{k}\right\}$. We then evaluate the social welfare function $W(u, x)$. Finally, we express the level of social welfare in terms of the price system by means of the social expenditure function $M(p, W)$.

We can decompose our money measure of social welfare into money measures of equity and efficiency. Equity reflects the gain in welfare from a more egalitarian distribution of a given total expenditure. Efficiency is the maximum level of social welfare that can be attained by lump-sum redistributions, so that welfare losses from an inequitable distribution of total expenditure are eliminated.

To define money measures of equity and efficiency we evaluate the social welfare function at the maximum that can be attained through lump-sum redistributions. This maximum is our measure of efficiency. Evaluating the social expenditure function at the potential level of welfare, we obtain aggregate expenditure $M$. This is our money measure of efficiency at the price system $p$.

Given a money measure of efficiency, we define a corresponding money measure of equity as the ratio between the money measure of actual social welfare $M(p, W)$ and the money measure of efficiency $M$. This measure of equity increases as the distribution of total expenditure approaches perfect equality. We express our money measure of social welfare as the product of efficiency and equity:

$$
M(p, W)=M \cdot\left(\frac{M(p, W)}{M}\right) .
$$

The critical feature of this decomposition is that all three measures are expressed in terms of the price system $p$.

27. Dalton (1920) and Hammond (1977). 


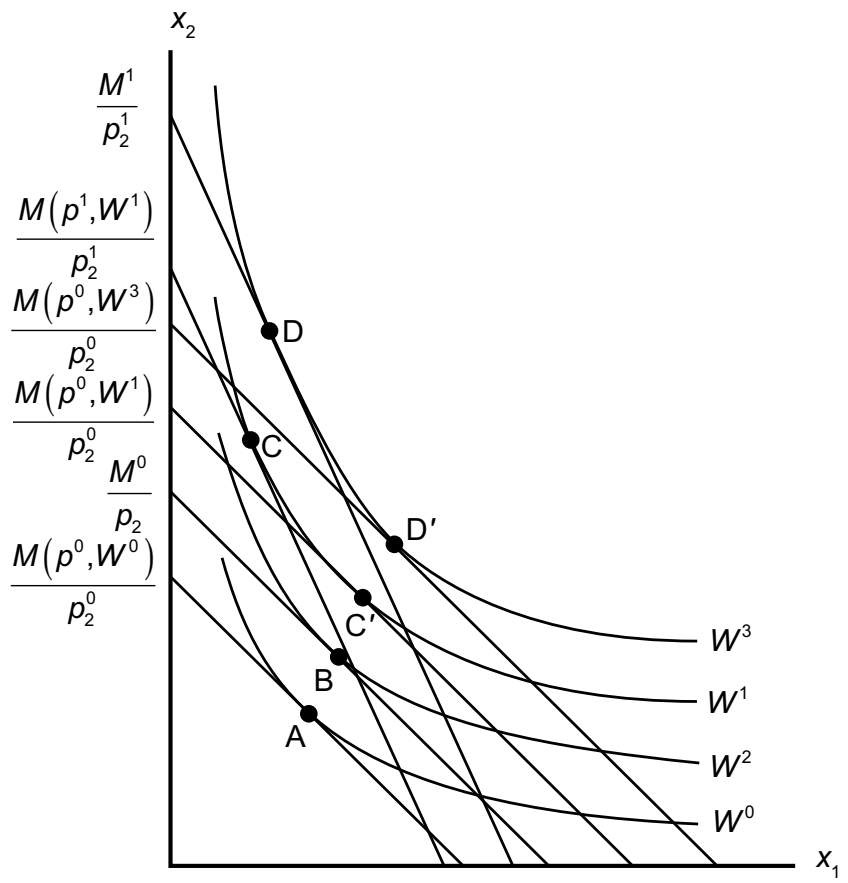

Fig. 3.2 Social standard of living and its cost

The social welfare function and the social expenditure function can be employed in defining measures of the standard of living and its cost. We illustrate these concepts geometrically in figure 3.2. The figure represents the indifference map of a representative consumer with preferences corresponding to the social expenditure function $M(p, W)$. This concept of a representative consumer was proposed by Samuelson (1956) and Pollak (1981).

For simplicity we consider the case of two commodities $(N=2)$, as before. Consumer equilibrium at the actual level of social welfare in the base period $W^{0}$ is represented by the point $A$. The corresponding level of aggregate expenditure $M\left(p^{0}, W^{0}\right)$, divided by the price of the second commodity $p_{2}^{0}$, is given on the vertical axis. This level provides a representation of aggregate expenditure in terms of units of the second commodity. Consumer equilibrium at the level of social welfare in the current period $W^{1}$ is represented by the point $C$.

To translate the level of social welfare $W^{1}$ into aggregate expenditure at the prices of the base period, we evaluate the social expenditure function at the price system $p^{0}$. Aggregate expenditure $M\left(p^{0}, W^{1}\right)$ corresponds to consumer equilibrium at the point $C^{\prime}$. The value of the social expenditure function at the potential level of welfare $W^{2}$, expressed in terms of the price 
system $p^{0}$, is $M^{0}$. The corresponding consumer equilibrium is represented by the point $B$.

Similarly, consumer equilibrium at the potential level of social welfare in the current period, say $W^{3}$, is presented by the point $D$. This is the maximum social welfare that can be attained through lump-sum redistributions of aggregate expenditure $M^{1}$ at current prices $p^{1}$. We translate this level of social welfare into expenditure at the base period price system $p^{0}$ by evaluating the expenditure function $M\left(p^{0}, W^{3}\right)$ at the consumer equilibrium represented by the point $D^{\prime}$.

The quantity index given by the ratio between levels of aggregate expenditure $M\left(p^{0}, W^{0}\right)$ and $M\left(p^{0}, W^{1}\right)$ is a measure of the actual standard of living. Similarly, the index represented by the ratio of the levels of aggregate expenditure $M\left(p^{0}, W^{3}\right)$ and $M^{0}$ is the measure of the potential standard of living. The ratio of the actual to the potential standard of living is the measure of equity. Finally, the price index given by the ratio between levels of expenditure $M^{1}$ and $M\left(p^{0}, W^{3}\right)$ is the measure of the social cost of living proposed by Pollak (1981).

\subsection{Implementing Measures of Individual and Social Welfare}

Our next objective is to implement money measures of individual and social welfare empirically. ${ }^{28}$ We require individual welfare functions that reflect the preference orderings of individual consuming units. For this purpose we employ an updated version of the econometric model of consumer behavior in the United States presented by Jorgenson and Slesnick (1987). ${ }^{29}$ This model is described in the appendix.

Our econometric model incorporates integrability restrictions that assure the existence of an indirect utility function. In the following section we construct indirect utility functions for all consuming units. In combining these utility functions with assumptions about horizontal and vertical equity, we develop numerical counterparts for the money measures of individual and social welfare in figures 3.1 and 3.2.

Our system of aggregate demand functions is obtained by summing over individual demand systems. Our model of individual demand incorporates cross-section data on quantities consumed, total expenditure, and attributes of households such as demographic characteristics. The aggregate quantities consumed depend on the attributes and total expenditure of individual consuming units through summary statistics of the joint distribution of total expenditure and attributes of individual households.

Exact aggregation is useful in simplifying the econometric modeling of

28. Implementation of measures of individual and social welfare is discussed by Slesnick (2001, 201-14).

29. This model was updated by Slesnick $(2001,96)$. 
aggregate consumer behavior. In fact, the special formulations of exact aggregation developed by William M. Gorman (1953) and Muellbauer (1976) were designed precisely for this purpose. ${ }^{30}$ We exploit the exact aggregation restrictions in constructing cardinal measures of individual welfare and defining interpersonal comparability in terms of household equivalence scales. We combine these measures of individual welfare with the assumptions on horizontal and vertical equity discussed below to measure social welfare.

To construct an econometric model based on exact aggregation, we first represent individual preferences by means of an indirect utility function for each consuming unit, using the following notation:

$w_{n k}=p_{n} x_{n k} / M_{k}$ : expenditure share of the $n$th commodity in the budget of the $k$ th consuming unit $(n=1,2, \ldots, N ; k=1,2, \ldots, K)$.

$w_{k}=\left(w_{1 k}, w_{2 k}, \ldots, w_{N k}\right)$ : vector of expenditure shares for the $k$ th consuming unit $(k=1,2, \ldots, K)$.

$\ln \left(p / M_{k}\right)=\left[\ln \left(p_{1} / M_{k}\right), \ln \left(p_{2} / M_{k}\right) \ldots, \ln \left(p_{N} / M_{k}\right)\right]$ : vector of logarithms of ratios of prices to expenditure by the $k$ th consuming unit $(k=1,2, \ldots, K)$. $\ln p=\left(\ln p_{1}, \ln p_{2}, \ldots, \ln p_{N}\right)$ : vector of logarithms of prices.

We assume that the $k$ th consuming unit allocates expenditures in accord with the transcendental logarithmic or translog indirect utility function, say $V_{k}$, where:

$$
\begin{aligned}
\ln V_{k} & =G\left(\ln \frac{p^{\prime}}{M_{k}} \alpha_{p}+\frac{1}{2} \ln \frac{p^{\prime}}{M_{k}} B_{p p} \ln \frac{p}{M_{k}}+\ln \frac{p^{\prime}}{M_{k}} B_{p A} A_{k}, A_{k}\right), \\
(k & =1,2, \ldots, K) .
\end{aligned}
$$

In this representation the function $G$ is a monotone increasing function of its first argument. The vector $\alpha_{p}$ and the matrices $B_{p p}$ and $B_{p A}$ are constant and the same for all consuming units. In addition, the function $G$ depends directly on the attribute vector $A_{k}$. This form of the indirect utility function is ordinal and noncomparable among consuming units. Measurability and interpersonal comparability of individual preferences are not required in modeling consumer behavior.

The expenditure shares of the $k$ th consuming unit can be derived by the logarithmic form of Roy's (1943) identity ${ }^{31}$

$$
w_{n k}=\frac{\left(\partial \ln V_{k}\right) /\left[\partial \ln \left(p_{n} / M_{k}\right)\right]}{\sum_{n=1}^{N}\left\{\left(\partial \ln V_{k}\right) /\left[\partial \ln \left(p_{n} / M_{k}\right)\right]\right\}},(n=1,2, \ldots, N ; k=1,2, \ldots, K) .
$$

Applying this identity to the translog indirect utility function (4), we obtain the system of individual expenditure shares 


$$
w_{k}=\frac{1}{D_{k}(p)}\left(\alpha_{p}+B_{p p} \ln \frac{p}{M_{k}}+B_{p A} A_{k}\right),(k=1,2, \ldots, K),
$$

where the denominators $\left\{D_{k}(p)\right\}$ take the form

$$
D_{k}(p)=i^{\prime} \alpha_{p}+i^{\prime} B_{p p} \ln \frac{p}{M_{k}}+i^{\prime} B_{p A} A_{k},(k=1,2, \ldots, K),
$$

and $i$ is a vector of ones.

The individual expenditure shares are homogeneous of degree zero in the unknown parameters $\alpha_{p}, B_{p p}, B_{p A}$. By multiplying a given set of parameters by a constant we obtain another set of parameters that generates the same system of individual budget shares. Accordingly, we can normalize the parameters without affecting observed patterns of individual expenditure allocation. We find it convenient to employ the normalization

$$
i^{\prime} \alpha_{p}=-1 \text {. }
$$

Under this restriction any change in the unknown parameters will be reflected in changes in individual expenditure patterns.

The conditions for exact aggregation are that the individual expenditure shares are linear in functions of the attributes $\left\{A_{k}\right\}$ and total expenditures $\left\{M_{k}\right\}$ for all consuming units. ${ }^{32}$ These conditions will be satisfied if and only if the terms involving the attributes and expenditures do not appear in the denominators of the expressions for the individual expenditure shares, so that:

$$
i^{\prime} B_{p A}=0, \text { and } i^{\prime} B_{p p} i=0 .
$$

The exact aggregation restrictions imply that the denominators $\left\{D_{k}(p)\right\}$ reduce to:

$$
D(p)=-1+i^{\prime} B_{p p} \ln p,
$$

where the subscript $k$ is no longer required, since the denominator is the same for all consuming units. Under these restrictions the individual expenditure shares can be written:

$$
w_{k}=\frac{1}{D(p)}\left(\alpha_{p}+B_{p p} \ln p-B_{p p} i \cdot \ln M_{k}+B_{p A} A_{k}\right),(k=1,2, \ldots, K) .
$$

The individual expenditure shares are linear in the logarithms of expenditures $\left\{\ln M_{k}\right\}$ and the attributes $\left\{A_{k}\right\}$, as required by exact aggregation.

To construct an econometric model of aggregate consumer behavior based on exact aggregation we obtain aggregate expenditure shares, say $w$, by multiplying individual expenditure shares (8) by expenditure for each consuming unit, adding over all consuming units, and dividing by aggregate expenditure, $M=\sum_{k=1}^{K} M_{k}$ and 


$$
w=\frac{\sum M_{k} w_{k}}{M} .
$$

The aggregate expenditure shares can be rewritten

$$
w=\frac{1}{D(p)}\left(\alpha_{p}+B_{p p} \ln p-B_{p p} i \frac{\sum M_{k} \ln M_{k}}{M}+B_{p A} \frac{\sum M_{k} A_{k}}{M}\right) .
$$

Aggregate expenditure patterns depend on the distribution of expenditure over all consuming units through summary statistics of the joint distribution of expenditures and attributes $-\sum M_{k} \ln M_{k} / M$ and $\left\{\sum M_{k} A_{k} / M\right\}$. Under exact aggregation systems of individual expenditure shares (8) for consuming units with identical demographic characteristics can be recovered in one and only one way from the system of aggregate expenditure shares (10). We next define cardinal measures of individual welfare that are fully comparable among individuals.

Under exact aggregation and integrability, the translog indirect utility function for the $k$ th consuming unit $V_{k}$ can be written:

$$
\begin{aligned}
\ln V_{k} & =\ln p^{\prime} \alpha_{p}+\frac{1}{2} \ln p^{\prime} B_{p p} \ln p-D(p) \ln \left[\frac{M_{k}}{m_{0}\left(p, A_{k}\right)}\right], \\
(k & =1,2, \ldots, K) .
\end{aligned}
$$

In this representation the function $m_{0}\left(p, A_{k}\right)$ is the general household equivalence scale and can be interpreted as the number of household equivalent members.

The general household equivalence scale takes the form:

$$
\begin{aligned}
\ln m_{0}\left(p, A_{k}\right)= & \frac{1}{D(p)} \\
& \cdot\left[\ln m\left(A_{k}\right)^{\prime} \alpha_{p}+\frac{1}{2} \ln m\left(A_{k}\right)^{\prime} B_{p p} \ln m\left(A_{k}\right)+\ln m\left(A_{k}\right)^{\prime} B_{p p} \ln p\right], \\
(k= & 1,2, \ldots, K),
\end{aligned}
$$

where:

$$
\ln m\left(A_{k}\right)=B_{p p}^{-1} B_{p A} A_{k},(k=1,2, \ldots, K) .
$$

This household equivalence scale has the key property identified by Lewbel (1989); namely, independence of the level of household welfare. We refer to the scales $\left\{m\left(A_{k}\right)\right\}$ as the commodity-specific translog household equivalence scales. ${ }^{33}$

Given the indirect utility function (11) for each consuming unit, we can

33. Alternative approaches to household equivalence scales are summarized by Slesnick (2001, 88-121). 
express total expenditure as a function of prices, the general household equivalence scale, and the level of utility:

$$
\begin{aligned}
\ln M_{k} & =\frac{1}{D(p)}\left[\ln p^{\prime}\left(\alpha_{p}+\frac{1}{2} B_{p p} \ln p\right)-\ln V_{k}\right]+\ln m_{0}\left(p, A_{k}\right), \\
(k & =1,2, \ldots, K) .
\end{aligned}
$$

We refer to this function as the translog individual expenditure function. The translog expenditure function gives the minimum level of expenditure required for the $k$ th consuming unit to achieve the utility level $V_{k}$, given the prices $p(k=1,2, \ldots, K)$.

The first step in measuring social welfare is to select representations of the individual welfare functions. We define individual welfare for the $k$ th consuming unit, say $W_{k}(k=1,2, \ldots, K)$, as the logarithm of the translog indirect utility function (11)

$$
\begin{aligned}
W_{k} & =\ln V_{k}=\ln p^{\prime} \alpha_{p}+\frac{1}{2} \ln p^{\prime} B_{p p} \ln p-D(p) \ln \left[\frac{M_{k}}{m_{0}\left(p, A_{k}\right)}\right], \\
(k & =1,2, \ldots, K) .
\end{aligned}
$$

It is important to emphasize that we have utilized the exact aggregation restrictions in establishing that the household equivalence scale is independent of the level of welfare.

At an intuitive level, the appeal of our measures of individual welfare is that they incorporate three types of information that are relevant to welfare measurement. Total expenditure $M_{k}$ corresponds to size of the household budget, while the number of household equivalent member $m_{0}\left(p, A_{k}\right)$ is an indicator of the size of the consuming unit. The budget and the size of the household are combined into a "per capita" measure of total expenditure.

Transforming expenditure per capita logarithmically implies that increments in individual welfare correspond to proportional changes in the resources of the household. Prices faced by the household enter through a linear transformation that is the same for all consuming units. Household size also depends on prices since the preferences of household members are not necessarily identical.

More formally, individual welfare is a linear function of the logarithm of total expenditure per household equivalent member $\ln \left[M_{k} / m_{0}\left(p, A_{k}\right)\right]$ with an intercept and slope coefficient that depends only on prices $p(k=1,2, \ldots, K)$. This property is invariant with respect to positive affine transformations that are the same for all consuming units, so that the individual welfare function provides a cardinal measure of individual welfare that is fully comparable among units. The incorporation of measures of individual welfare into a social welfare function requires a normative judgment about horizontal 
equity. We assume that every individual should be treated symmetrically with any other individual having the same welfare function. ${ }^{34}$

To represent social orderings in a form suitable for measuring social welfare, we consider the class of social welfare functions introduced by Jorgenson and Slesnick (1983):

$$
W(u, x)=\ln \bar{V}-\gamma(x)\left[\frac{\sum_{k=1}^{K} m_{0}\left(p, A_{k}\right)\left|\ln V_{k}-\ln \bar{V}\right|^{-\rho}}{\sum_{k=1}^{K} m_{0}\left(p, A_{k}\right)}\right]^{-1 / \rho} .
$$

The first term in the social welfare functions (16) corresponds to an average of individual welfare levels over all consuming units:

$$
\begin{aligned}
\ln \bar{V} & =\frac{\sum_{k=1}^{K} m_{0}\left(p, A_{k}\right) \ln V_{k}}{\sum_{k=1}^{K} m_{0}\left(p, A_{k}\right)} \\
& =\ln p^{\prime}\left(\alpha_{p}+\frac{1}{2} B_{p p} \ln p\right)-D(p) \frac{\sum_{k=1}^{K} m_{0}\left(p, A_{k}\right) \ln \left\{M_{k} /\left[m_{0}\left(p, A_{k}\right)\right]\right\}}{\sum_{k=1}^{K} m_{0}\left(p, A_{k}\right)} .
\end{aligned}
$$

The second term is a linear homogeneous function of deviations of levels of individual welfare from the average and is a measure of dispersion in individual welfare levels. These social welfare functions are invariant with respect to positive affine transformations and provide cardinal measures of social welfare.

The parameter $\rho$ determines the curvature of the social welfare function in the individual welfare functions $\left\{W_{k}(x)\right\}$. We refer to this parameter as the degree of aversion to inequality. The range of admissible values of $\rho$ is from negative unity to negative infinity. By selecting an appropriate value of this parameter, we can incorporate ethical judgments about vertical equity into the social welfare function.

The measure of dispersion vanishes in the limiting case where the degree of aversion to inequality $\rho$ is equal to negative infinity. The social welfare function reduces to an average of welfare levels over all consuming units. We refer to this as the utilitarian social welfare function. This limiting case gives the least possible weight to equity considerations.

We also consider the limiting case where $\rho$ is equal to negative unity in order to give the greatest weight to equity considerations. We refer to this as the egalitarian social welfare function. For the applications in the following section, we present measures of social welfare for both utilitarian and egalitarian cases in order to highlight the role of normative considerations in social welfare measurements.

At this point we have generated a class of social welfare functions capable of expressing the implications of a variety of normative judgments. The Pareto principle requires that an increase in individual welfare must increase

34. Lewbel (1989) suggested that this approach could also be employed for the AIDS system proposed by Deaton and Muellbauer (1980). Details are provided by Fleurbaey and Hammond (2004). 
social welfare. This condition implies that the increase in the average level of individual welfare must exceed the increase in the dispersion in individual welfare. We assume that the function $\gamma(x)$ must take the maximum value consistent with the Pareto principle. This assumption gives maximum weight to the second term in equation (16), representing equity considerations.

The intuition underlying the class of social welfare functions (16) is that we augment the mean of individual welfare with a measure of dispersion. This class includes the utilitarian social welfare functions based on average social welfare and frequently used in policy evaluation. Allowing for dispersion makes it possible to give additional weight to equity considerations.

In order to determine the form of the social expenditure function $M(p, W)$, we maximize the social welfare function (16) for a fixed level of aggregate expenditure by equalizing total expenditure per household equivalent member $M_{k} /\left[m_{0}\left(p, A_{k}\right)\right]$ for all consuming units. For the translog indirect utility function, this takes the form:

$$
\ln \bar{V}=\ln p^{\prime}\left(\alpha_{p}+\frac{1}{2} B_{p p} \ln p\right)-D(p) \ln \left[\frac{M}{\sum_{k=1}^{K} m^{0}\left(p, A_{k}\right)}\right] .
$$

The maximum level of welfare that is potentially available is our measure of efficiency and does not depend on the degree of aversion to inequality $\rho$.

If aggregate expenditure is distributed so as to equalize total expenditure per household equivalent member, the level of individual welfare is the same for all consuming units and the social welfare function reduces to the average level of individual welfare $\ln \bar{V}$. The value of social welfare is obtained by evaluating the translog indirect utility function at total expenditure per household equivalent member $M /\left[\sum_{k=1}^{K} m_{0}\left(p, A_{k}\right)\right]$ for the economy as a whole. This is an algebraic representation of the preferences of the representative consumer depicted in figure 3.2.

We can express aggregate expenditure as a function of the level of social welfare and prices:

$$
\ln M(p, W)=\frac{1}{D(p)}\left[\ln p^{\prime}\left(\alpha_{p}+\frac{1}{2} B_{p p} \ln p\right)-W\right]+\ln \left[\sum_{k=1}^{K} m_{0}\left(p, A_{k}\right)\right] .
$$

The value of aggregate expenditure is obtained by evaluating the translog individual expenditure function (14) at the level of social welfare $W$ and the number of household equivalent members $\sum_{k=1}^{K} m_{0}\left(p, A_{k}\right)$ for the economy as a whole. This is the social expenditure function used in constructing the measures of the social standard of living and its cost represented in figure 3.2 .

\subsection{Measuring Welfare in the US National Accounts}

We turn next to the measurement of social welfare in the US national accounts. The first issue to be addressed is: Why incorporate welfare into the national accounts? The advantages stem from the accuracy and reliability 
of estimates carried out within a system of national accounts. Finally, the results can be reported with other estimates from the national accounts on a regular basis - annually, quarterly, or even monthly.

The next issue to be addressed is: Why use the new architecture? The national accounts incorporate the double-entry bookkeeping associated with systems of private accounts. Each account in the new architecture is expressed in both current and constant prices, so that the benefits of doubleentry bookkeeping are multiplied by a factor of two. This "quadruple entry" bookkeeping is characteristic of national accounting, but is not usually employed in private accounting.

Another advantage of measuring welfare within the national accounts is the establishment of international standards like those that underlie the 2008 SNA. The resulting uniformity of methods is essential for international comparability. The 2008 SNA rules out a welfare interpretation of the national accounts, but systems of satellite accounts, such as environmental accounts, are often given a welfare interpretation. ${ }^{35}$ Based on experience with the 2008 SNA and its predecessors, the incorporation of welfare measures into the national accounts will require lengthy international consultations.

As an illustration of international comparability, the World Bank's estimates of poverty and inequality are very valuable in comparing economic performance and social progress across countries. ${ }^{36}$ These estimates are based on hundreds of microeconomic data sets for different countries providing information on income and consumption for individuals and households. The estimates also incorporate purchasing power comparisons of production in the World Bank's International Comparisons Project. ${ }^{37}$

In January 2008, the new architecture was endorsed by the Advisory Committee on Measuring Innovation in the Twenty-first Century Economy to the US secretary of commerce Carlos Guttierez: ${ }^{38}$

The proposed new "architecture" for the NIPAs (US national income and product accounts) would consist of a set of income statements, balance sheets, flow of funds statements, and productivity estimates for the entire economy and by sector that are more accurate and internally consistent. ${ }^{39}$

In response to the recommendations of the Advisory Committee on Innovation, the Bureau of Economic Analysis (BEA) and the Bureau of Labor Statistics (BLS) produced an integrated production account in May 2009,

35. See 2008 SNA, United Nations (2009, ch. 2, 12-13; ch. 29, 534-8). This issue will be discussed in more detail below.

36. See Chen and Ravallion (2010). A recent summary is provided by Ravallion (2012). A critique of the World Bank's approach is given by Deaton (2010).

37. World Bank (2008).

38. Advisory Committee on Measuring Innovation in the Twenty-First Century Economy (2008).

39. The Advisory Committee on Measuring Innovation in the Twenty-First Century Economy $(2008,8)$. 


\section{PRODUCTION}

Gross Domestic Product Equals

Gross Domestic Factor Outlay

\section{DOMESTIC RECEIPTS} AND EXPENDITURES

Domestic Receipts Equal

Domestic Expenditure

\section{DOMESTIC CAPITAL ACCOUNT}

Gross Domestic Capital Formation Equals Gross Domestic Savings

\section{DOMESTIC BALANCE SHEET}

Domestic Wealth Equals

Domestic Tangible Assets and

U.S. Net International Position

\author{
3. FOREIGN TRANSACTION CURRENT ACCOUNT \\ Receipts from Rest of World Equal \\ Payments to Rest of World and \\ Balance on Current Account
}

5. FOREIGN TRANSACTION CAPITAL ACCOUNT

Balance on Current Account Equals

Payments to Rest of the World and

Net Lending or Borrowing

\section{U.S. INTERNATIONAL POSITION}

U.S.-Owned Assets Abroad Equal

Foreign-Owned Assets in U.S. and

U.S. Net International Position

Fig. 3.3 New architecture for an expanded and integrated set of national accounts for the United States

linking multifactor productivity with the NIPAs. ${ }^{40}$ This was a critical step in implementing the new architecture. ${ }^{41}$ The omission of productivity statistics from the NIPAs and the United Nations' System of National Accounts (SNA) had been a serious barrier to application of the national accounts in assessing the sources of economic growth. Estimates of productivity are also essential for projecting potential economic growth. ${ }^{42}$

In August 2008, four years after the meeting of the Conference on Research in Income and Wealth devoted to the new architecture, Jorgenson presented an update of the prototype system of national accounts he had developed with Landefeld. The occasion was Jorgenson's Richard and Nancy Ruggles Memorial Lecture to the Thirtieth General Conference of the International Association for Research on Income and Wealth. ${ }^{43}$ Jorgenson linked the new architecture presented in figure 3.3 to the integrated macroeconomic accounts developed by the BEA and the FRB.

Jorgenson presented the GDP as a measure of production and personal consumption expenditures, and as a component of potential social welfare.

40. Harper et al. (2009). For current data from the integrated production account, see http:// www.bea.gov/national/integrated_prod.htm.

41. For a more detailed discussion, see Jorgenson (2011).

42. See Jorgenson, Ho, and Stiroh (2008).

43. Dale W. Jorgenson (2009). 
He emphasized that consumption is a measure of the current flow of welfare. Saving, the second component of domestic expenditures, is a measure of current contributions to future welfare through consumption. ${ }^{44}$

Jorgenson's Ruggles lecture focused primarily on integrating productivity measures into the national accounts. ${ }^{45}$ The Domestic Income and Product Account is presented in table 3.1. In the prototype system of national accounts this account is modeled after Jorgenson's presidential address to the American Economic Association. ${ }^{46}$ Like the BEA/BLS Integrated Production Account, this conforms to the standards presented in Schreyer's (2001) OECD productivity manual.

A key innovation in the new architecture for the US national accounts is the inclusion of prices and quantities of capital services for all productive assets in the US economy. The process that led to the 2008 SNA was formally initiated by the United Nations Statistical Commission in March 2004, almost simultaneously with the development of the new architecture for the US national accounts. Issues related to the measurement of capital were assigned to an expert group, designated Canberra II after the site of the initial meeting in Canberra, Australia.

The incorporation of the price and quantity of capital services into the 2008 SNA was recommended by the Canberra II expert group and approved by the United Nations Statistical Commission at its February-March 2007 meeting. Schreyer, then head of national accounts at the OECD, prepared an OECD manual titled Measuring Capital. ${ }^{47}$ Schreyer's manual provided detailed recommendations on methods for the construction of prices and quantities of capital services.

Estimates of capital services like those used in the new architecture were discussed in chapter 20 of the 2008 SNA:

By ... associating estimates of capital services with the standard breakdown of value added, the contributions of both (labor) and capital to production can be portrayed in a form ready for use in the analysis of productivity in a way entirely consistent with the accounts of the SNA. ${ }^{48}$

Jorgenson concluded that the Domestic Income and Product Account of the new architecture is consistent with the 2008 SNA. The volume measure of input is a quantity index of capital and labor services, while the volume

44. This interpretation has been developed by Samuelson (1961), Nordhaus and Tobin (1973), Weitzman (1976), and Weitzman (2003).

45. Issues in measuring productivity were considered by a statistical working party of the OECD Industry Committee, headed by Edwin Dean, former associate commissioner for productivity and technology of the BLS. The working party established international standards for productivity measurement at both aggregate and industry levels. The results are summarized in Schreyer (2001).

46. Jorgenson (2001).

47. Schreyer (2009).

48. 2008 SNA, United Nations (2009, ch.20, 415). 


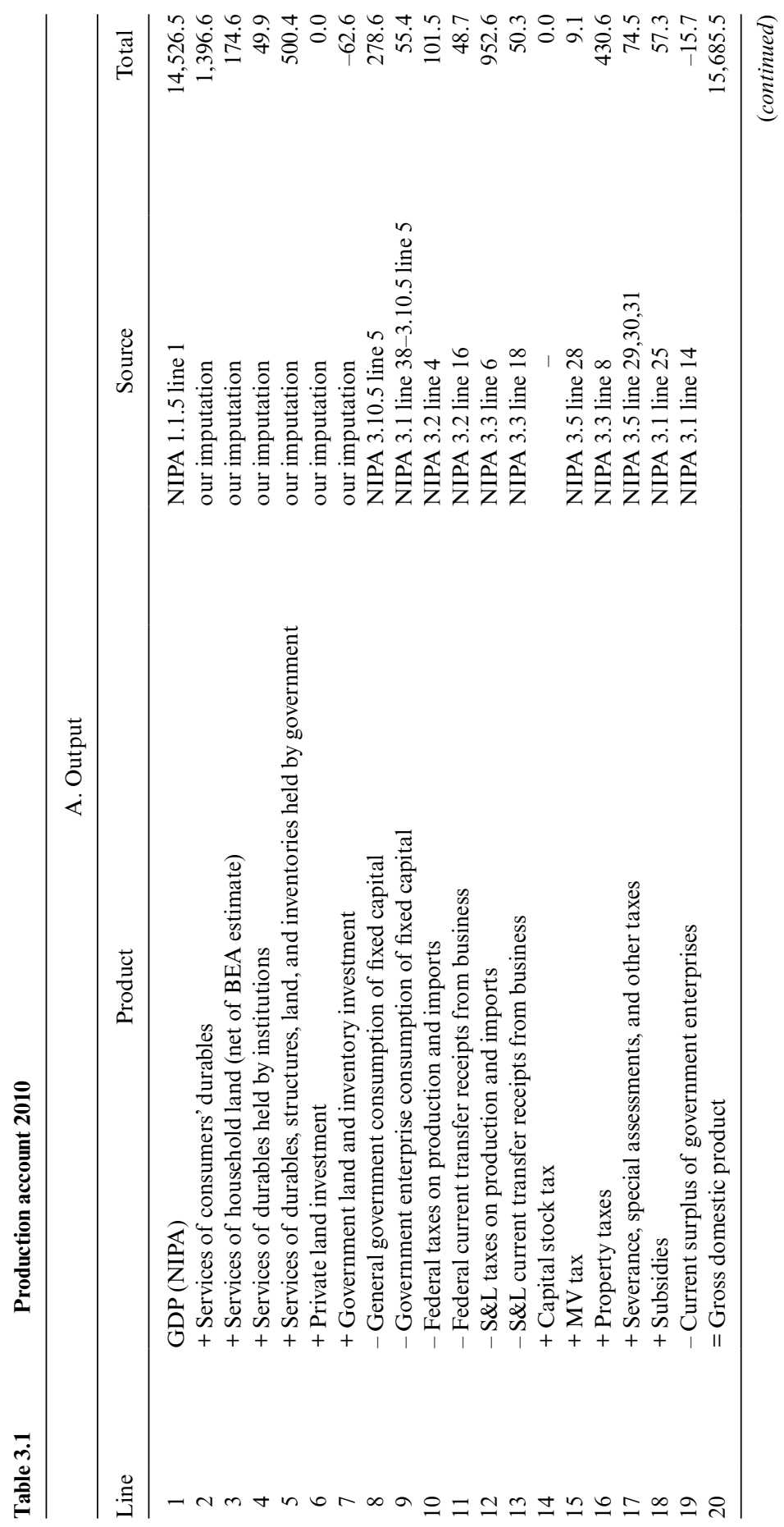







measure of output is a quantity index of investment and consumption goods. Productivity is the ratio of output to input.

The interpretation of output, input, and productivity requires the production possibility frontier introduced by Jorgenson (1966): ${ }^{49}$

$$
Y(I, C)=A X(K, L),
$$

gross domestic product in constant prices $Y$ consists of outputs of investment goods $I$ and consumption goods $C$. These products are produced from capital services $K$ and labor services $L$. These factor services are components of gross domestic income in constant prices $X$ and are augmented by multifactor productivity $A$.

The key feature of the production possibility frontier is the explicit role for changes in the relative prices of investment and consumption outputs. The aggregate production function is a competing methodology, but there is no role for separate prices of investment and consumption goods. Under the assumption that product and factor markets are in competitive equilibrium, the share-weighted growth of outputs is the sum of the share-weighted growth of inputs and growth in multifactor productivity:

$$
\bar{w}_{I} \Delta I+\bar{w}_{C} \Delta \ln C=\bar{v}_{K} \Delta \ln K+\bar{v}_{L} \Delta \ln L+\Delta \ln A,
$$

where $w$ and $v$ denote average shares of the outputs and inputs, respectively, in the value of GDP.

Table 3.2 presents accounts for the sources of US economic growth during 1948 to 2010 and various subperiods. For the period as a whole, the contribution of capital services accounted for 51.6 percent of economic growth. Labor services contributed 31.6 percent, while multifactor productivity growth contributed only 19.0 percent. The first subperiod ends with the business cycle peak in 1973. After strong output and productivity growth in the 1950s, 1960s, and early 1970s, the growth of GDP dropped from 3.95 percent from 1948 to 1973 to only 2.68 percent from 1973 through 1995 .

A powerful resurgence in US economic growth began in 1995 but ended abruptly in 2000 with the dot-com crash. United States economic growth surged to 4.14 percent during the period 1995 to 2000 . This reflected the investment boom of the late 1990s, as businesses, households, and governments poured resources into plant and equipment, especially computers, software, and communications equipment. Between 1973 and 1995 and 1995 to 2000 , the contribution of capital input to US economic growth jumped by 0.80 percentage points, accounting for more than half the increase in output growth of 1.45 percent. The contribution of labor input increased by a modest 0.17 percent, while multifactor productivity growth accelerated by 0.49 percent.

After the dot-com crash in 2000, GDP growth slowed to 2.87 percent per 


\begin{tabular}{|c|c|c|c|c|c|c|}
\hline & 1948-2010 & $1948-1973$ & 1973-1995 & 1995-2000 & $2000-2005$ & 2005-2010 \\
\hline \multicolumn{7}{|c|}{ Output } \\
\hline Gross domestic product & 3.18 & 3.95 & 2.68 & 4.14 & 2.87 & 0.94 \\
\hline $\begin{array}{c}\text { Contribution of } \\
\text { consumption }\end{array}$ & 2.29 & 2.79 & 1.96 & 2.33 & 2.26 & 1.27 \\
\hline $\begin{array}{l}\text { Contribution of } \\
\text { investment }\end{array}$ & 0.89 & 1.16 & 0.72 & 1.81 & 0.61 & -0.33 \\
\hline \multicolumn{7}{|c|}{ Growth } \\
\hline Gross domestic income & 2.59 & 2.93 & 2.52 & 3.49 & 2.05 & 1.07 \\
\hline $\begin{array}{l}\text { Contribution of capital } \\
\text { services }\end{array}$ & 1.64 & 1.88 & 1.40 & 2.20 & 1.58 & 1.05 \\
\hline $\begin{array}{l}\text { Contribution of labor } \\
\text { services }\end{array}$ & 0.95 & 1.06 & 1.12 & 1.29 & 0.24 & 0.03 \\
\hline Multifactor productivity & 0.59 & 1.02 & 0.16 & 0.65 & 0.83 & -0.14 \\
\hline
\end{tabular}

year and the relative importance of investment in information technology declined sharply. The contribution of capital services to economic growth dropped by 0.62 percent per year. The growth of multifactor productivity increased to 0.83 percent, while the contribution of labor input sank by more than a full percentage point to 0.24 percent per year. The GDP growth plunged to only 0.94 percent during 2005 to 2010 , a subperiod that includes the Great Recession of 2007 to 2009.

The results presented in table 3.2 highlight the importance of the new architecture. In the absence of an integrated production account, like that published by the BEA and BLS in 2009, the analysis of sources of economic growth would have had to rely on a mixture of estimates from different sources, combined with estimates of missing information, such as growth in labor input per hour worked. Different analysts could readily produce conflicting interpretations of events such as the spurt in productivity growth after 1995, and the collapse of output and productivity growth during the Great Recession.

The Domestic Income and Product Account of the new architecture has been disaggregated to the level of sixty-five industries by Susan Fleck, Steven Rosenthal, Matthew Russell, Erich Strassner, and Lisa Usher (chapter 11, this volume). ${ }^{50}$ Jorgenson, Ho, and Samuels (2012) have extended this industry-level account to cover the period 1947 to $2010 .{ }^{51}$ The methodology follows that of Jorgenson, Ho, and Stiroh (2008), and conforms to the international standards established in Schreyer's (2001) OECD productivity

50. Fleck et al. (chapter 11, this volume). For data covering 1998-2010, see http://www .bea.gov/industry/pdf/Prototype $\% 20$ BEA-BLS $\% 20$ Industry-Level $\% 20$ Production $\% 20$ Account $\% 20$ for $\% 20$ the $\% 20$ United $\% 20$ States $\% 201998-2010 \_$Final.pdf.

51. Jorgenson, Ho, and Samuels (2012). 
manual. Jorgenson and Schreyer (2013) have shown how to integrate the industry-level production account of Jorgenson, Ho, and Samuels (2012) into the 2008 SNA. ${ }^{52}$

Industry-level production accounts have been incorporated into the national accounts in seven countries in addition to the United States. The EU KLEMS project has developed systems of production accounts for the economies of twenty-five of the twenty-seven European Union (EU) member states..$^{53}$ For major EU countries this project includes accounts for seventy-two industries, covering the period 1970 to 2005. The World KLEMS Initiative will extend the EU KLEMS framework to important developing and transition economies, including Argentina, Brazil, Chile, China, India, Indonesia, Mexico, Russia, Turkey, and Taiwan. ${ }^{54}$

We employ the Domestic Income and Expenditures Account presented in table 3.3 in measuring individual and social welfare in the new architecture. The key accounting identity for the Domestic Income and Expenditures Account is that net income is equal to net expenditures. Net income includes gross income from sales of capital and labor services from the Domestic Income and Product Account, less depreciation. Net income also contains net receipts from the rest of the world, including taxes and transfers. Net expenditures are the sum of personal consumption expenditures, government consumption expenditures, and net saving. ${ }^{55}$

Economic growth creates opportunities for both present and future consumption. These opportunities are generated by expansion in the supply of capital and labor services, augmented by changes in the level of living:

$$
Z(C, S)=B W(L, N),
$$

net domestic expenditures in constant prices $Z$ consist of consumption expenditures $C$ and saving $S$, net of depreciation. These expenditures are generated by net incomes in constant prices $W$, comprising labor incomes $L$ and property incomes $N$, net of depreciation.

The level of living $B$ must be carefully distinguished from multifactor productivity $A$. An increase in the level of living implies that for given supplies of the factor services that generate labor and property incomes, the US economy generates greater opportunities for present and future consumption. The share-weighted growth of expenditures is the sum of the share-weighted growth of incomes and growth in the level of living:

52. Jorgenson and Schreyer (2013).

53. The EU KLEMS project was completed on June 30, 2008. A summary of the findings is presented by Timmer et al. (2010), and Mas and Stehrer (2012). For current estimates see www.euklems.net/.

54. Jorgenson (2012). See http://www.csls.ca/ipm/24/IPM-24-Jorgenson.pdf. Jorgenson summarizes the prototype industry-level production account for the United States developed by Jorgenson, Ho, and Samuels (2012).

55. Jorgenson (2009, table 3, 15), expresses the Domestic Income and Expenditures Account in terms of the US National Income and Product Accounts. 


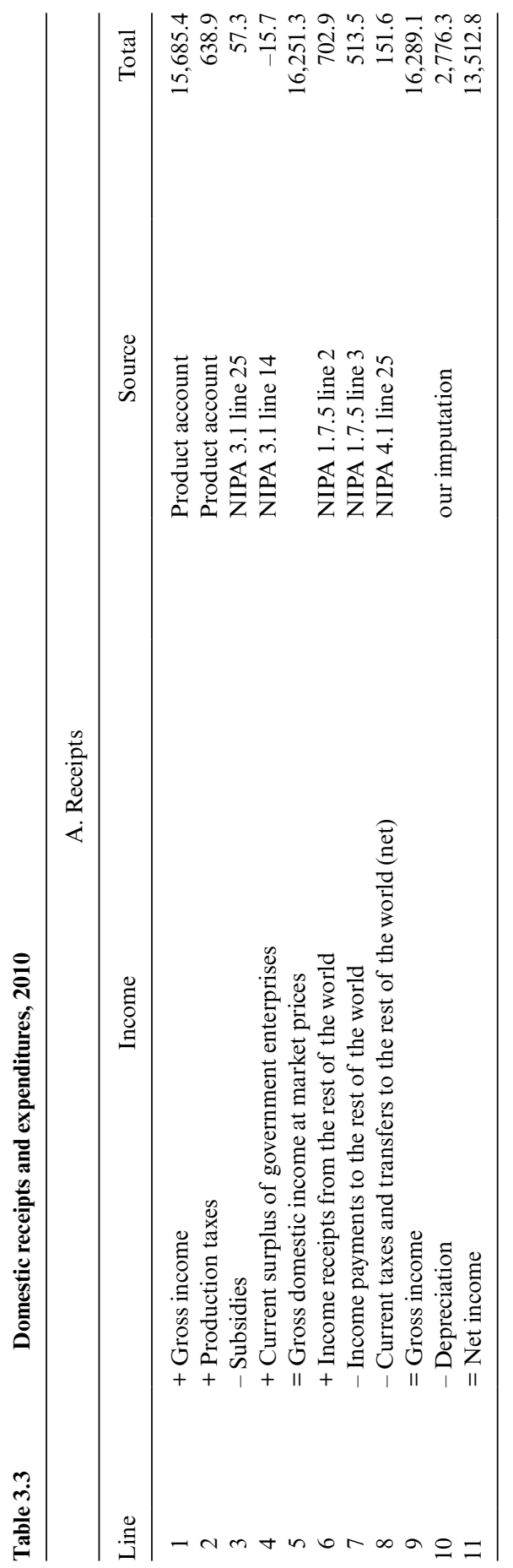




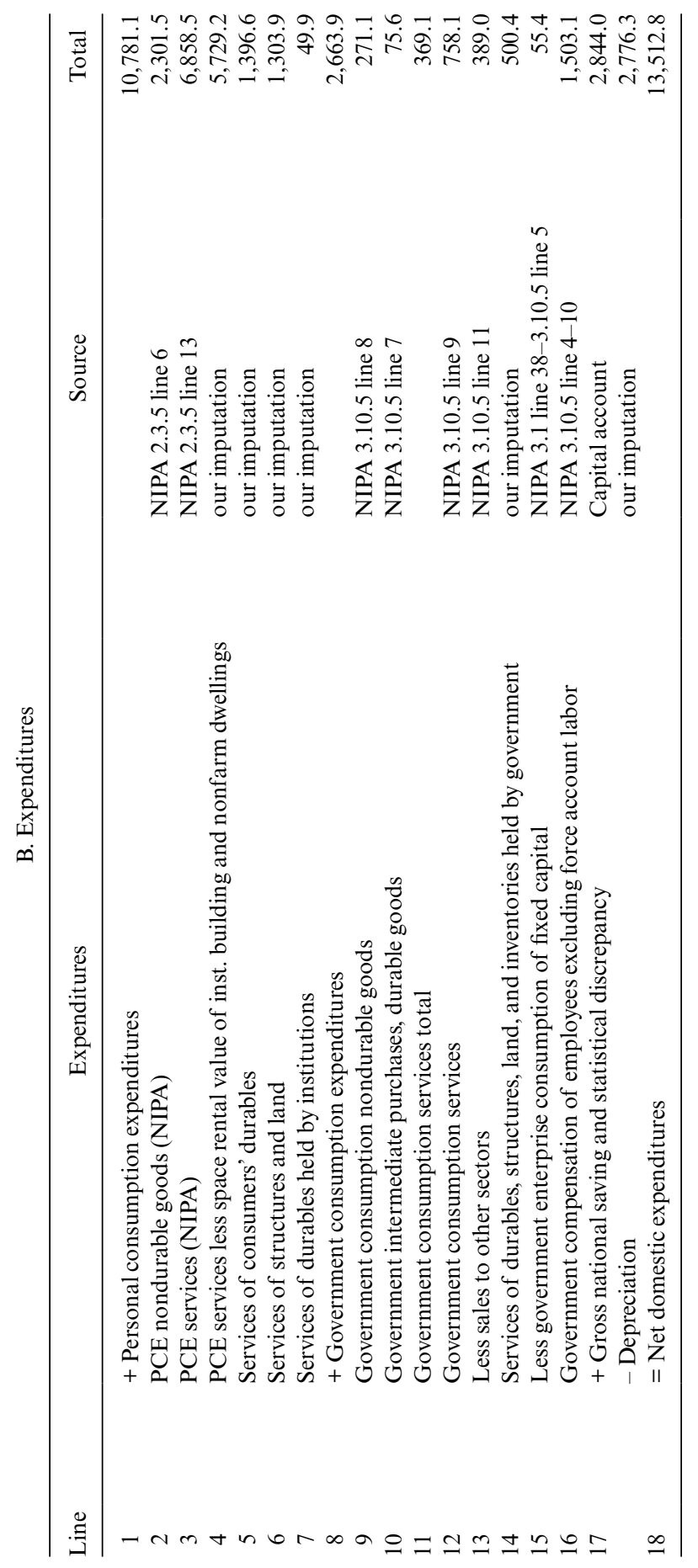




$$
\bar{w}_{C} \Delta \ln C+\bar{w}_{S} \Delta S=\bar{v}_{L} \Delta \ln L+\bar{v}_{N} \Delta \ln N+\Delta \ln B,
$$

where $w$ and $v$ denote average value shares for expenditures and incomes, respectively.

Table 3.4 presents a decomposition of the uses of economic growth for the period 1948 to 2010. The growth rate of expenditures is a weighted average of growth rates of personal consumption expenditures, government consumption expenditures, and net saving. The contribution of each category of expenditures is the growth rate weighted by the relative share. Similarly, the contributions of labor and property incomes are the growth rates weighted by the relative shares. Growth in the level of living is the difference between growth rates of expenditures and incomes.

The growth of net expenditures largely reflects the pattern of output growth, but averaged 0.25 percent lower for the period 1948 to 2010 . Strong growth in expenditures during the period 1948 to 1973 was followed by a slowdown after 1973. A sharp revival occurred after 1995, but the boom was followed by another slowdown after 2000 and a collapse after 2005. Personal consumption expenditures, a key component of our measure of potential welfare, greatly predominated as a source of growth in the net expenditures. The contribution of net saving added 0.16 percent to growth of expenditures for the period as a whole, but this contribution declined sharply after 2000 .

\begin{tabular}{|c|c|c|c|c|c|c|}
\hline & \multicolumn{6}{|c|}{ Average annual growth rates } \\
\hline & $1948-2010$ & $1948-1973$ & 1973-1995 & $1995-2000$ & $2000-2005$ & 2005-2010 \\
\hline \multicolumn{7}{|c|}{ Receipts } \\
\hline Domestic receipts & 2.24 & 2.70 & 2.15 & 3.02 & 1.14 & 0.68 \\
\hline $\begin{array}{l}\text { Contribution of labor } \\
\text { income }\end{array}$ & 1.08 & 1.19 & 1.29 & 1.48 & 0.28 & 0.02 \\
\hline $\begin{array}{l}\text { Contribution of net } \\
\text { property income }\end{array}$ & 1.16 & 1.51 & 0.86 & 1.54 & 0.86 & 0.66 \\
\hline Level of living & 0.74 & 1.03 & 0.56 & 0.90 & 1.17 & -0.46 \\
\hline \multicolumn{7}{|c|}{ Expenditures } \\
\hline Net expenditures & 2.99 & 3.73 & 2.71 & 3.91 & 2.31 & 0.23 \\
\hline $\begin{array}{c}\text { Contribution of } \\
\text { consumption }\end{array}$ & 2.82 & 3.34 & 2.44 & 3.34 & 2.72 & 1.50 \\
\hline $\begin{array}{l}\text { Contribution of } \\
\text { personal consumption }\end{array}$ & 2.36 & 2.69 & 2.07 & 3.12 & 2.45 & 1.12 \\
\hline $\begin{array}{l}\text { Contribution of } \\
\text { government } \\
\text { consumption }\end{array}$ & 0.46 & 0.65 & 0.37 & 0.21 & 0.27 & 0.37 \\
\hline $\begin{array}{l}\text { Contribution of net } \\
\text { saving }\end{array}$ & 0.16 & 0.39 & 0.27 & 0.57 & -0.42 & -1.27 \\
\hline
\end{tabular}




\subsection{Standard of Living and Its Cost}

In this section we integrate distributional measures for personal consumption expenditures into the US national accounts for the period 1948 to 2010. Measurement of the standard of living and its cost are classic problems in the application of normative economics. ${ }^{56}$ Measurement of the standard of living is the objective of the approach to evaluating national income introduced by John Hicks (1940) and discussed by Samuelson (1950). ${ }^{57}$ John Chipman and James Moore have demonstrated that the compensation principle proposed by Hicks provides a valid indicator of social welfare only if preferences are identical and homothetic for all consuming units. ${ }^{58}$ Sen $(1976,1979)$ has revived interest in this problem, applying rank-order weights to elements of the matrix $x$ that describes the social state. ${ }^{59} \mathrm{Ham}$ mond (1978) has shown that Sen's approach requires preferences of the type considered by Gorman (1953) for its validity. ${ }^{60}$

Fisher, Johnson, and Smeeding (2012) provide a detailed survey of the recent literature on the measurement of inequality in consumption and income. ${ }^{61}$ Their estimates of inequality employ data from the Consumer Expenditure Survey (CEX) and cover the period 1984 to 2010. Other recent and comprehensive studies of welfare measurement based on the CEX include Attanasio, Hurst, and Pistaferri (2012) and Meyer and Sullivan (2009). ${ }^{62}$ Our approach is complementary to the work of Fixler and Johnson (chapter 8, this volume), who consider the integration of distributional measures for income from the Current Population Survey (CPS) into the US national accounts. ${ }^{63}$

We next implement the approach to normative economics presented in section 3.2. Our measure of potential social welfare is personal consumption expenditures from the Domestic Income and Expenditures Account of figure 3.3, expressed in constant prices per household equivalent member. Actual social welfare also depends on the distribution of personal consumption expenditures over the population.

We first introduce a quantity index of social welfare, say $Q_{A}$, as a measure of the standard of living. We define this index as the ratio of two levels of aggregate expenditure per capita

56. Measurement of the standard of living and its cost is discussed by Jorgenson and Slesnick (1983), Jorgenson and Slesnick (1990), and Slesnick (2001, 67-121).

57. See Hicks (1940) and Samuelson (1950).

58. Chipman and Moore $(1973,1980)$.

59. Sen $(1976,1979)$.

60. Hammond (1978).

61. See Fisher, Johnson, and Smeeding (2012).

62. See Attanasio, Hurst, and Pistaferri (2012) and Meyer and Sullivan (2009). This short list of references is far from exhaustive.

63. Fixler and Johnson (chapter 8, this volume). 


$$
Q_{A}\left(p^{0}, W^{0}, W^{1}\right)=\frac{M\left(p^{0}, W^{1}\right) / \sum_{k=1}^{K^{1}} m_{0}\left(p^{0}, A_{k}\right)}{M\left(p^{0}, W^{0}\right) / \sum_{k=1}^{K^{0}} m_{0}\left(p^{0}, A_{k}\right)} .
$$

The numerator is the expenditure per capita required to attain the current level of social welfare $W^{1}$ at base period prices $p^{0}$. The denominator is the expenditure per capita required for the base period level of welfare $W^{0}$. Our measure of the size of the population is the number of household equivalent members.

We obtain the base level of social welfare $W^{0}$ by evaluating the social welfare function at the price system $p^{0}$ and the distribution of total expenditure $\left\{M_{k}^{0}\right\}$. To obtain the current level of social welfare $W^{1}$ we evaluate the social welfare function at the current price system $p^{1}$ and the distribution of total expenditure $\left\{M_{k}^{1}\right\}$. Using the social expenditure function (18), we express the quantity index of social welfare (19) in the form

$$
\ln Q_{A}\left(p^{0}, W^{0}, W^{1}\right)=\frac{1}{D\left(p^{0}\right)}\left(W^{0}-W^{1}\right) .
$$

We refer to the index $Q_{A}$ as the translog standard-of-living index. If this index is greater than unity, actual social welfare has increased; otherwise, social welfare has remained the same or decreased.

Next, we decompose the index of social welfare (20) into the product of efficiency and equity. We first determine the maximum level of welfare, say $W^{3}$, that can be attained through lump-sum redistributions of aggregate total expenditure $M^{1}=\sum M_{k}^{1}$. Expenditure must be distributed so as to equalize individual expenditure per capita, so that the social welfare function reduces to average individual welfare (17)

(21) $W^{3}=\ln \bar{V}^{1}=\ln p^{1^{\prime}}\left(\alpha_{p}+\frac{1}{2} B_{p p} \ln p^{1}\right)-D\left(p^{1}\right) \ln \left[M^{1 /} / \sum_{k=1}^{K^{1}} m_{0}\left(p^{1}, A_{k}\right)\right]$.

This is our measure of efficiency and does not depend on the degree of aversion to inequality $\rho$.

We define efficiency, say $Q_{p}$, as the ratio of two levels of aggregate expenditure per capita

$$
\begin{aligned}
Q_{p}\left(p^{0}, W^{2}, W^{3}\right) & =\frac{M\left(p^{0}, W^{3}\right) / \sum_{k=1}^{K^{1}} m_{0}\left(p^{0}, A_{k}\right)}{M\left(p^{0}, W^{2}\right) / \sum_{k=1}^{K^{0}} m_{0}\left(p^{0}, A_{k}\right)} \\
& =\frac{M\left(p^{0}, W^{3}\right) / \sum_{k=1}^{K^{1}} m_{0}\left(p^{0}, A_{k}\right)}{M^{0} / \sum_{k=1}^{K^{0}} m_{0}\left(p^{0}, A_{k}\right)},
\end{aligned}
$$

where $M^{0}$ is base period expenditure.

The quantity index of efficiency (22) is the ratio of money measures of efficiency in the current period and the base period, both evaluated at the base period price system $p^{0}$. The numerator is the per capita expenditure required to attain the potential level of social welfare in the current period 
$W^{3}$. The denominator of (22) is the expenditure per capita required for the potential level of welfare in the base period $W^{2}$.

We express potential levels of social welfare in the base period $W^{2}$ and the current period $W^{3}$ in terms of average individual welfare (17). Using the social expenditure function, we express the quantity index of efficiency (22) in the form

$$
\ln Q_{p}\left(p^{0}, W^{2}, W^{3}\right)=\frac{1}{D\left(p^{0}\right)}\left(W^{2}-W^{3}\right) .
$$

We refer to the index $Q_{p}$ as the translog efficiency index. If this index is greater than unity, potential social welfare has increased; otherwise, potential welfare has remained the same or decreased.

Finally, we define equity, say $Q_{E}$ as the ratio of the index of social welfare to the index of efficiency

$$
Q_{E}=\frac{Q_{A}}{Q_{p}}=\frac{M\left(p^{0}, W^{1}\right) / M\left(p^{0}, W^{3}\right)}{M\left(p^{0}, W^{0}\right) / M^{0}} .
$$

The numerator of our quantity index of equity (24) is a money measure of equity in the current period. Similarly, the denominator is the money measure of equity in the base period. Since measures of equity depend on the degree of aversion to inequality $\rho$, we present indexes for both utilitarian and egalitarian social welfare functions.

Using the social expenditure function, we express the quantity index of equity (24) in the form

$$
\ln Q_{E}\left(p^{0}, W^{0}, W^{1}, W^{2}, W^{3}\right)=\frac{1}{D\left(p^{0}\right)}\left[\left(W^{0}-W^{1}\right)-\left(W^{2}-W^{3}\right)\right],
$$

and refer to the index $Q_{E}$ as the translog equity index. If this index is greater than unity, equity has increased; otherwise, equity has remained the same or decreased. ${ }^{64}$

The social welfare function (16) provides a cardinal measure of social welfare. Since the translog indexes of the standard of living, efficiency, and equity are proportional to differences between values of this social welfare function, they also provide cardinal measures. Growth rates of these indexes are cardinal measures of changes in social welfare.

To define a social cost-of-living index we first consider the ratio of nominal expenditure per capita, as follows:

$$
\ln \frac{M^{1} / \sum_{k=1}^{K^{1}} m_{0}\left(p^{1}, A_{k}\right)}{M^{0} / \sum_{k=1}^{K^{0}} m_{0}\left(p^{0}, A_{k}\right)}=\ln \frac{M\left(p^{1}, W^{3}\right) / \sum_{k=1}^{K^{1}} m_{0}\left(p^{1}, A_{k}\right)}{M\left(p^{0}, W^{2}\right) / \sum_{k=1}^{K^{0}} m_{0}\left(p^{0}, A_{k}\right)} .
$$

64. This approach to the measurement of inequality was introduced by Jorgenson and Slesnick (1984), and is discussed by Jorgenson (1990), Jorgenson and Slesnick (1990), Slesnick (1994), and Slesnick (2001, 122-55). 
Base period expenditure $M^{0}$ is a money measure of potential social welfare, evaluated at base period prices $p^{0}$. Similarly, current expenditure $M^{1}$ is a measure of potential welfare at current prices $p^{1}$.

Next, we decompose nominal expenditure (26) into the product of an index of efficiency and a social cost-of-living index,

$$
\ln \frac{M^{1} / \sum_{k=1}^{K^{1}} m_{0}\left(p^{1}, A_{k}\right)}{M^{0} / \sum_{k=1}^{K^{0}} m_{0}\left(p^{0}, A_{k}\right)}=\ln Q_{p}+\ln P,
$$

where $Q_{p}$ is the translog index of efficiency (23) and the index $P$ is the translog social cost-of-living index introduced by Jorgenson and Slesnick (1983),

$$
\begin{aligned}
\ln P\left(p^{1}, p^{0}, W^{3}\right)= & \ln M^{1}-\frac{1}{D\left(p^{0}\right)}\left[\ln p^{0^{\prime}}\left(\alpha_{p}+B_{p p} \ln p^{0}\right)-W^{3}\right] \\
& +\ln \sum_{k=1}^{K^{1}} m_{0}\left(p^{0}, A_{k}\right) .
\end{aligned}
$$

The social cost-of-living index is the ratio of the aggregate expenditure required to attain the potential level of welfare in the current period $W^{3}$ at current prices $p^{1}$ to the expenditure required to attain this level of welfare at base period prices $p^{0}$. This depends only on potential social welfare $W^{3}$ and is independent of the degree of aversion to inequality $\rho$. If the translog social cost-of-living index is greater than unity and aggregate expenditure is constant, then social welfare is decreased by the change in prices.

As an illustration of the standard of living $Q_{A}$ in (19) and the cost-of-living $P$ in (27), we assess the impact of changes in the price system $p$ and the distribution of total expenditure $\left\{M_{k}\right\}$ on the standard of living for both utilitarian and egalitarian social welfare functions. In the first column of table 3.5 we present personal consumption expenditures for the United States in nominal terms for the period 1948 to 2010 . This is aggregate expenditure $M$, the sum of total expenditure over all US households $\sum_{k=1}^{K} M_{k}$.

In the second column of table 3.5, we present the translog social cost-ofliving index $P$ from equation (27). We divide consumption in nominal terms by the social cost-of-living index to obtain personal consumption expenditures in constant prices of 2005 in the third column. In the fourth column of table 3.5 we present the number of household equivalent members $\sum_{k=1}^{K} m_{0}\left(p, A_{k}\right)$ of the US population. We divide personal consumption expenditures in real terms by the number of household equivalent members to express real consumption in per capita terms. This results in a measure of potential social welfare that is proportional to the translog efficiency index $Q_{p}$ in (22).

In table 3.6 we present indexes of the US standard of living for both utilitarian and egalitarian social welfare functions to emphasize the role of normative conditions in measuring social welfare. In the first column of table 3.6 we present the translog equity index $Q_{E}$ in (24), evaluated for the 


\begin{tabular}{|c|c|c|c|c|c|}
\hline Year & $\begin{array}{c}\text { Personal } \\
\text { consumption } \\
\text { expenditures } \\
\text { (billions) }\end{array}$ & $\begin{array}{c}\text { Cost-of-living } \\
\text { index } \\
(2005=1.0000)\end{array}$ & $\begin{array}{c}\text { Personal } \\
\text { consumption } \\
\text { expenditures, } \\
\text { quantity (2005 } \\
\text { dollars) }\end{array}$ & $\begin{array}{l}\text { Number of } \\
\text { household } \\
\text { equivalent } \\
\text { members } \\
\text { (millions) }\end{array}$ & $\begin{array}{l}\text { Personal consumption } \\
\text { expenditures, quantity per } \\
\text { household equivalent } \\
\text { member (thousands of } \\
2005 \text { dollars) }\end{array}$ \\
\hline 1948 & 176.1 & 0.1483 & $1,187.7$ & 247.4 & 4.80 \\
\hline 1949 & 179.2 & 0.1472 & $1,217.8$ & 245.8 & 4.95 \\
\hline 1950 & 191.3 & 0.1490 & $1,284.0$ & 248.1 & 5.18 \\
\hline 1951 & 210.1 & 0.1563 & $1,344.3$ & 250.8 & 5.36 \\
\hline 1952 & 223.5 & 0.1597 & $1,399.8$ & 252.6 & 5.54 \\
\hline 1953 & 235.8 & 0.1634 & $1,443.1$ & 256.1 & 5.63 \\
\hline 1954 & 244.5 & 0.1654 & $1,478.0$ & 262.3 & 5.63 \\
\hline 1955 & 261.4 & 0.1678 & $1,557.9$ & 269.8 & 5.77 \\
\hline 1956 & 274.8 & 0.1702 & $1,614.4$ & 272.4 & 5.93 \\
\hline 1957 & 290.4 & 0.1750 & $1,659.5$ & 276.0 & 6.01 \\
\hline 1958 & 302.0 & 0.1783 & $1,693.6$ & 280.4 & 6.04 \\
\hline 1959 & 323.2 & 0.1827 & $1,768.9$ & 280.2 & 6.31 \\
\hline 1960 & 337.8 & 0.1861 & $1,815.2$ & 290.9 & 6.24 \\
\hline 1961 & 350.3 & 0.1883 & $1,860.0$ & 296.1 & 6.28 \\
\hline 1962 & 370.1 & 0.1916 & $1,932.0$ & 295.2 & 6.54 \\
\hline 1963 & 388.5 & 0.1943 & $1,998.9$ & 295.3 & 6.77 \\
\hline 1964 & 417.5 & 0.1982 & $2,105.8$ & 298.3 & 7.06 \\
\hline 1965 & 449.8 & 0.2024 & $2,221.7$ & 298.1 & 7.45 \\
\hline 1966 & 486.9 & 0.2080 & $2,340.2$ & 299.2 & 7.82 \\
\hline 1967 & 514.3 & 0.2130 & $2,414.4$ & 303.5 & 7.96 \\
\hline 1968 & 558.6 & 0.2210 & $2,528.1$ & 306.5 & 8.25 \\
\hline 1969 & 606.7 & 0.2312 & $2,624.0$ & 309.8 & 8.47 \\
\hline 1970 & 654.1 & 0.2417 & $2,706.2$ & 312.9 & 8.65 \\
\hline 1971 & 703.6 & 0.2526 & $2,785.1$ & 317.6 & 8.77 \\
\hline 1972 & 771.0 & 0.2628 & $2,934.1$ & 320.7 & 9.15 \\
\hline 1973 & 847.1 & 0.2755 & $3,075.2$ & 328.5 & 9.36 \\
\hline 1974 & 932.2 & 0.3011 & $3,095.7$ & 329.5 & 9.40 \\
\hline 1975 & $1,036.5$ & 0.3265 & $3,174.3$ & 332.7 & 9.54 \\
\hline 1976 & $1,156.7$ & 0.3490 & $3,314.2$ & 335.0 & 9.89 \\
\hline 1977 & $1,283.0$ & 0.3727 & $3,442.8$ & 339.0 & 10.16 \\
\hline 1978 & $1,434.3$ & 0.3985 & $3,599.6$ & 342.4 & 10.51 \\
\hline 1979 & $1,599.5$ & 0.4298 & $3,721.3$ & 350.6 & 10.61 \\
\hline 1980 & $1,775.2$ & 0.4712 & $3,767.1$ & 352.0 & 10.70 \\
\hline 1981 & $1,969.3$ & 0.5153 & $3,822.0$ & 348.7 & 10.96 \\
\hline 1982 & $2,118.6$ & 0.5474 & $3,870.2$ & 344.6 & 11.23 \\
\hline 1983 & $2,317.9$ & 0.5749 & $4,031.6$ & 342.5 & 11.77 \\
\hline 1984 & $2,524.2$ & 0.6008 & $4,201.5$ & 355.6 & 11.82 \\
\hline 1985 & $2,720.8$ & 0.6183 & $4,400.7$ & 360.6 & 12.20 \\
\hline 1986 & $2,876.0$ & 0.6318 & $4,551.8$ & 353.1 & 12.89 \\
\hline 1987 & $3,092.6$ & 0.6545 & $4,725.3$ & 364.9 & 12.95 \\
\hline 1988 & $3,344.1$ & 0.6811 & $4,910.1$ & 375.2 & 13.09 \\
\hline 1989 & $3,593.7$ & 0.7097 & $5,063.4$ & 375.3 & 13.49 \\
\hline 1990 & $3,848.6$ & 0.7412 & $5,192.6$ & 377.0 & 13.78 \\
\hline 1991 & $4,025.9$ & 0.7671 & $5,248.3$ & 388.5 & 13.51 \\
\hline
\end{tabular}


Table 3.5

(continued)

\begin{tabular}{cccccc}
\hline Yersonal & $\begin{array}{c}\text { Personal } \\
\text { consumption } \\
\text { expenditures } \\
\text { (billions) }\end{array}$ & $\begin{array}{c}\text { Cost-of-living } \\
\text { index } \\
(2005=1.0000)\end{array}$ & $\begin{array}{c}\text { Number of } \\
\text { consumption } \\
\text { expenditures, } \\
\text { quantity (2005 } \\
\text { dollars) }\end{array}$ & $\begin{array}{c}\text { household } \\
\text { equivalent } \\
\text { members } \\
\text { (millions) }\end{array}$ & $\begin{array}{c}\text { Personal consumption } \\
\text { expenditures, quantity per } \\
\text { household equivalent } \\
\text { member (thousands of } \\
\text { 2005 dollars) }\end{array}$ \\
\hline 1992 & $4,270.7$ & 0.7902 & $5,404.2$ & 385.3 & 14.03 \\
1993 & $4,491.3$ & 0.8057 & $5,574.3$ & 389.1 & 14.32 \\
1994 & $4,759.0$ & 0.8248 & $5,770.0$ & 393.8 & 14.65 \\
1995 & $5,001.9$ & 0.8422 & $5,939.2$ & 410.9 & 14.45 \\
1996 & $5,295.4$ & 0.8631 & $6,135.4$ & 411.6 & 14.91 \\
1997 & $5,588.1$ & 0.8794 & $6,354.7$ & 422.0 & 15.06 \\
1998 & $5,888.7$ & 0.8835 & $6,665.1$ & 423.3 & 15.75 \\
1999 & $6,267.9$ & 0.8955 & $6,999.2$ & 435.0 & 16.09 \\
2000 & $6,720.3$ & 0.9150 & $7,344.9$ & 445.2 & 16.84 \\
2001 & $7,020.8$ & 0.9270 & $7,573.4$ & 449.8 & 17.19 \\
2002 & $7,312.7$ & 0.9376 & $7,799.5$ & 453.8 & 17.44 \\
2003 & $7,662.7$ & 0.9534 & $8,036.9$ & 460.8 & 17.76 \\
2004 & $8,086.0$ & 0.9731 & $8,309.7$ & 467.8 & 18.26 \\
2005 & $8,620.1$ & 1.0000 & $8,620.1$ & 472.0 & 18.67 \\
2006 & $9,118.1$ & 1.0245 & $8,900.1$ & 476.6 & 18.77 \\
2007 & $9,618.3$ & 1.0535 & $9,130.1$ & 481.4 & 18.26 \\
2008 & $10,008.0$ & 1.0894 & $9,186.6$ & 489.5 & 18.36 \\
2009 & $10,019.0$ & 1.1062 & $9,057.5$ & 496.1 & \\
2010 & $10,383.1$ & 1.1273 & $9,210.4$ & 501.6 & \\
\hline & & & & & \\
\hline
\end{tabular}

egalitarian social welfare function (16) with $\rho$ equal to negative unity. The egalitarian measure of social welfare is proportional to the translog social welfare index $Q_{A}$ in (20), ${ }^{65}$ expressed in constant prices of 2005. Similarly, the utilitarian standard of living presented in the fifth column of table 3.6 is evaluated for the utilitarian social welfare function with $\rho$ equal to negative infinity. This is our utilitarian measure social welfare, expressed in constant prices of 2005.

Finally, in the third column of table 3.6 we present the egalitarian index of relative inequality. This is defined as the proportional loss in money metric social welfare due to an unequal distribution of household welfare:

$$
I\left(p^{0}, W^{1}, W^{3}\right)=1-\frac{M\left(p^{0}, W^{1}\right)}{M\left(p^{0}, W^{3}\right)} .
$$

Like the familiar Gini coefficient, this index of relative inequality lies between zero and one with zero defining perfect equality. We present the utilitarian index of relative inequality in the sixth column of table 3.6.

65. For measures covering the years 1947-1985, see Jorgenson (1990) and Jorgenson and Slesnick (1990). 


\begin{tabular}{|c|c|c|c|c|c|c|}
\hline \multirow[b]{2}{*}{ Year } & \multicolumn{3}{|c|}{ Egalitarian } & \multicolumn{3}{|c|}{ Utilitarian } \\
\hline & $\begin{array}{c}\text { Equity } \\
(2005=1.0000)\end{array}$ & $\begin{array}{c}\text { Standard } \\
\text { of living } \\
\text { (thousands of } \\
\text { 2005 dollars) }\end{array}$ & $\begin{array}{l}\text { Relative } \\
\text { inequality }\end{array}$ & $\begin{array}{c}\text { Equity } \\
(2005=1.0000)\end{array}$ & $\begin{array}{c}\text { Standard } \\
\text { of living } \\
\text { (thousands of } \\
2005 \text { dollars) }\end{array}$ & $\begin{array}{l}\text { Relative } \\
\text { inequality }\end{array}$ \\
\hline 1948 & 0.881 & 2.56 & 0.4658 & 0.941 & 3.58 & 0.2538 \\
\hline 1949 & 0.880 & 2.64 & 0.4666 & 0.940 & 3.69 & 0.2547 \\
\hline 1950 & 0.905 & 2.84 & 0.4516 & 0.955 & 3.92 & 0.2423 \\
\hline 1951 & 0.904 & 2.94 & 0.4517 & 0.955 & 4.06 & 0.2422 \\
\hline 1952 & 0.906 & 3.05 & 0.4504 & 0.956 & 4.20 & 0.2418 \\
\hline 1953 & 0.899 & 3.07 & 0.4548 & 0.951 & 4.25 & 0.2454 \\
\hline 1954 & 0.897 & 3.07 & 0.4559 & 0.950 & 4.25 & 0.2463 \\
\hline 1955 & 0.896 & 3.14 & 0.4570 & 0.948 & 4.35 & 0.2476 \\
\hline 1956 & 0.911 & 3.27 & 0.4475 & 0.957 & 4.50 & 0.2403 \\
\hline 1957 & 0.907 & 3.31 & 0.4500 & 0.955 & 4.56 & 0.2425 \\
\hline 1958 & 0.912 & 3.34 & 0.4471 & 0.957 & 4.59 & 0.2404 \\
\hline 1959 & 0.952 & 3.64 & 0.4229 & 0.981 & 4.91 & 0.2219 \\
\hline 1960 & 0.990 & 3.75 & 0.3998 & 1.003 & 4.97 & 0.2045 \\
\hline 1961 & 0.990 & 3.77 & 0.3997 & 1.003 & 5.00 & 0.2044 \\
\hline 1962 & 0.999 & 3.96 & 0.3944 & 1.008 & 5.23 & 0.2004 \\
\hline 1963 & 1.006 & 4.13 & 0.3900 & 1.012 & 5.43 & 0.1973 \\
\hline 1964 & 1.013 & 4.33 & 0.3859 & 1.015 & 5.69 & 0.1945 \\
\hline 1965 & 1.018 & 4.60 & 0.3825 & 1.018 & 6.02 & 0.1922 \\
\hline 1966 & 1.023 & 4.85 & 0.3796 & 1.021 & 6.33 & 0.1904 \\
\hline 1967 & 1.028 & 4.96 & 0.3769 & 1.023 & 6.46 & 0.1886 \\
\hline 1968 & 1.032 & 5.16 & 0.3741 & 1.025 & 6.71 & 0.1868 \\
\hline 1969 & 1.036 & 5.32 & 0.3716 & 1.027 & 6.90 & 0.1852 \\
\hline 1970 & 1.040 & 5.46 & 0.3691 & 1.029 & 7.06 & 0.1837 \\
\hline 1971 & 1.046 & 5.56 & 0.3660 & 1.031 & 7.18 & 0.1817 \\
\hline 1972 & 1.050 & 5.82 & 0.3635 & 1.034 & 7.50 & 0.1799 \\
\hline 1973 & 1.071 & 6.08 & 0.3507 & 1.044 & 7.75 & 0.1719 \\
\hline 1974 & 1.064 & 6.06 & 0.3547 & 1.041 & 7.76 & 0.1743 \\
\hline 1975 & 1.060 & 6.13 & 0.3570 & 1.038 & 7.86 & 0.1761 \\
\hline 1976 & 1.057 & 6.34 & 0.3588 & 1.037 & 8.14 & 0.1775 \\
\hline 1977 & 1.053 & 6.49 & 0.3613 & 1.034 & 8.33 & 0.1795 \\
\hline 1978 & 1.049 & 6.69 & 0.3640 & 1.031 & 8.60 & 0.1818 \\
\hline 1979 & 1.044 & 6.72 & 0.3672 & 1.028 & 8.66 & 0.1843 \\
\hline 1980 & 1.039 & 6.74 & 0.3701 & 1.025 & 8.70 & 0.1869 \\
\hline 1981 & 1.051 & 6.99 & 0.3626 & 1.033 & 8.98 & 0.1807 \\
\hline 1982 & 1.056 & 7.19 & 0.3596 & 1.035 & 9.23 & 0.1785 \\
\hline 1983 & 1.040 & 7.42 & 0.3693 & 1.025 & 9.57 & 0.1869 \\
\hline 1984 & 1.025 & 7.35 & 0.3783 & 1.016 & 9.53 & 0.1936 \\
\hline 1985 & 1.020 & 7.55 & 0.3815 & 1.013 & 9.81 & 0.1961 \\
\hline 1986 & 1.026 & 8.02 & 0.3778 & 1.017 & 10.40 & 0.1934 \\
\hline 1987 & 1.030 & 8.09 & 0.3753 & 1.019 & 10.47 & 0.1914 \\
\hline 1988 & 1.018 & 8.08 & 0.3825 & 1.010 & 10.49 & 0.1984 \\
\hline 1989 & 1.037 & 8.48 & 0.3713 & 1.022 & 10.94 & $\begin{array}{c}0.1893 \\
\text { (continued) }\end{array}$ \\
\hline
\end{tabular}


Table 3.6

(continued)

\begin{tabular}{|c|c|c|c|c|c|c|}
\hline \multirow[b]{2}{*}{ Year } & \multicolumn{3}{|c|}{ Egalitarian } & \multicolumn{3}{|c|}{ Utilitarian } \\
\hline & $\begin{array}{c}\text { Equity } \\
(2005=1.0000)\end{array}$ & $\begin{array}{c}\text { Standard } \\
\text { of living } \\
\text { (thousands of } \\
2005 \text { dollars) }\end{array}$ & $\begin{array}{l}\text { Relative } \\
\text { inequality }\end{array}$ & $\begin{array}{c}\text { Equity } \\
(2005=1.0000)\end{array}$ & $\begin{array}{c}\text { Standard } \\
\text { of living } \\
\text { (thousands of } \\
2005 \text { dollars) }\end{array}$ & $\begin{array}{c}\text { Relative } \\
\text { inequality }\end{array}$ \\
\hline 1990 & 1.032 & 8.62 & 0.3744 & 1.018 & 11.12 & 0.1925 \\
\hline 1991 & 1.0393 & 8.51 & 0.3698 & 1.0258 & 10.99 & 0.1862 \\
\hline 1992 & 1.0323 & 8.78 & 0.3741 & 1.0189 & 11.34 & 0.1916 \\
\hline 1993 & 1.0396 & 9.03 & 0.3697 & 1.0247 & 11.64 & 0.1872 \\
\hline 1994 & 1.0466 & 9.30 & 0.3654 & 1.0277 & 11.94 & 0.1848 \\
\hline 1995 & 1.0456 & 9.16 & 0.3661 & 1.0277 & 11.78 & 0.1848 \\
\hline 1996 & 1.0401 & 9.40 & 0.3693 & 1.0240 & 12.11 & 0.1877 \\
\hline 1997 & 1.0249 & 9.36 & 0.3785 & 1.0152 & 12.13 & 0.1946 \\
\hline 1998 & 1.0280 & 9.82 & 0.3767 & 1.0167 & 12.70 & 0.1934 \\
\hline 1999 & 1.0101 & 9.86 & 0.3875 & 1.0035 & 12.81 & 0.2039 \\
\hline 2000 & 1.0107 & 10.11 & 0.3871 & 1.0052 & 13.16 & 0.2025 \\
\hline 2001 & 1.0069 & 10.28 & 0.3894 & 1.0017 & 13.38 & 0.2053 \\
\hline 2002 & 1.0304 & 10.74 & 0.3752 & 1.0165 & 13.86 & 0.1936 \\
\hline 2003 & 1.0119 & 10.70 & 0.3865 & 1.0085 & 13.95 & 0.2000 \\
\hline 2004 & 1.0207 & 10.99 & 0.3811 & 1.0112 & 14.25 & 0.1978 \\
\hline 2005 & 1.0000 & 11.07 & 0.3936 & 1.0000 & 14.49 & 0.2067 \\
\hline 2006 & 1.0022 & 11.35 & 0.3923 & 1.0008 & 14.82 & 0.2061 \\
\hline 2007 & 1.0020 & 11.52 & 0.3924 & 0.9993 & 15.04 & 0.2072 \\
\hline 2008 & 0.9956 & 11.33 & 0.3963 & 0.9965 & 14.84 & 0.2095 \\
\hline 2009 & 1.0029 & 11.10 & 0.3919 & 1.0017 & 14.51 & 0.2053 \\
\hline 2010 & 0.9815 & 10.93 & 0.4049 & 0.9885 & 14.40 & 0.2158 \\
\hline
\end{tabular}

In table 3.7 we present average growth rates for personal consumption expenditures in constant prices per household equivalent member, our measure of efficiency, for the postwar period 1948 to 2010, and for five subperiods. We also present growth rates of egalitarian and utilitarian measures of equity and the standard of living. The average annual growth rate of efficiency for the period as a whole was 2.16 percent. The average growth rate of the egalitarian measure of the standard of living was 2.34 percent, reflecting a modest gain in equity of 0.17 percent per year. For the utilitarian measure of the standard of living the growth rate was 2.24 percent and the growth rate of equity was only 0.08 percent.

Growth of equity was limited to the subperiod 1948 to 1973 for both egalitarian and utilitarian measures. Equity declined modestly during 1973 to $1995,0.11$ percent per year for the egalitarian measure, and 0.07 for the utilitarian measure. For the subperiod 2000 to 2005, these rates of decline were 0.21 for the egalitarian measure and 0.10 for the utilitarian measure. For both measures equity plunged during the investment boom of 1995 to 2000 and again during the Great Recession of 2005 to 2010. The egalitarian 


\begin{tabular}{lcccccr}
\hline & \multicolumn{6}{c}{ Average annual growth rates } \\
\cline { 2 - 7 } & $1948-2010$ & $1948-1973$ & $1973-1995$ & $1995-2000$ & $2000-2005$ & $2005-2010$ \\
\hline & & \multicolumn{7}{c}{ Egalitarian } \\
Standard of living & 2.34 & 3.45 & 1.87 & 1.96 & 1.82 & -0.27 \\
$\quad$ Efficiency & 2.16 & 2.67 & 1.97 & 2.65 & 2.03 & 0.11 \\
Equity & 0.17 & 0.78 & -0.11 & -0.68 & -0.21 & -0.37 \\
& & \multicolumn{7}{c}{ Utilitarian } \\
Standard of living & 2.24 & 3.09 & 1.90 & 2.20 & 1.93 & -0.12 \\
$\quad$ Efficiency & 2.16 & 2.67 & 1.97 & 2.65 & 2.03 & 0.11 \\
$\quad$ Equity & 0.08 & 0.42 & -0.07 & -0.44 & -0.10 & -0.23 \\
\hline
\end{tabular}

measure declined by 0.68 percent per year during 1995 to 2000 and 0.37 percent during 2005 to 2010. For the utilitarian measure these rates were 0.44 and 0.23 percent per year, respectively, for these two subperiods.

The growth rate of efficiency was highest during the period 1948 to 1973. Since this is the only period when the growth of equity was positive, the growth rates of the standard of living were also highest for both egalitarian and utilitarian measures. The growth rate of efficiency dropped during the subperiod 1973 to 1995 . Combined with the modest declines in equity, this resulted in a substantial decline in the growth rates of both egalitarian and utilitarian measures of the standard of living.

The growth rate of efficiency revived briefly during the investment boom of 1995 to 2000, falling short of its postwar peak. This growth rate dropped again during 2000 to 2005 and was barely positive during the Great Recession period of 2005 to 2010 . For the egalitarian measure of equity the investment boom growth in efficiency was more than offset by the substantial decline in equity, so that the growth rate of the standard of living continued its downward course. This continued during 2000 to 2005 and became negative during the Great Recession after 2005 . The decline in equity was less substantial for the utilitarian measure, so that the growth rate of the standard of living rose modestly during 1995 to 2000 before falling in 2000 to 2005 and becoming negative during the Great Recession.

The modest differences between egalitarian and utilitarian growth rates of the standard of living illustrate the importance of value judgments in measuring social welfare. However, the qualitative picture is very similar for the two measures. High growth rates during 1948 to 1973 were followed by lower but relatively stable growth rates for 1973 to 2005, and by a collapse during the Great Recession period of 2005 to 2010. For both measures, the investment boom of 1995 to 2000 was largely offset by an accelerated decline in equity. Finally, substantial declines in equity contributed to the collapse of the standard of living during the Great Recession for both measures. 


\subsection{Conclusion}

We conclude by recommending that distributional information should be incorporated into the US national accounts. This process could begin with a satellite system for measuring social welfare that would include the two polar opposite social welfare functions that we have considered. The egalitarian social welfare function gives maximum weight to equity considerations, while the utilitarian social welfare functions gives these considerations minimum weight.

The satellite system for measuring social welfare could include a breakdown of our measures of social welfare by family size, age of head of household, region, race, and urban versus rural residence and gender of head of household. A breakdown could also be provided by personal consumption expenditures per family. Using data sets on consumption from sources such as the World Bank and the Luxembourg Income Study, together with prices of consumption from sources like the World Bank's International Comparison Project, the satellite system could provide international comparisons. ${ }^{66}$

Incorporating normative judgments into the national accounts is a substantial departure from a long tradition. This tradition, as reflected in SNA 2008, excludes normative judgments that are essential for interpreting distributional information. The traditional view is that economists have little to contribute to these judgments. Our view is that the development of the economic theory of social choice and its many applications has made many economists expert in using normative perspectives in the evaluation of economic policy. These perspectives should be reflected in the US national accounts.

The strengths of the traditional approach to the national accounts could be preserved by presenting distributional information in a satellite system and considering a number of alternatives. Well-established aggregates from the production, income and expenditure, and wealth accounts, such as the GDP, personal consumption expenditures, and national wealth should be retained in the core system of national accounts. These are essential for developing and interpreting distributional information within the framework of the new architecture for the US national accounts.

The boundary of social welfare could be extended to include nonmarket goods and services and measures of subjective well-being. Alan B. Krueger (2009) and his coauthors have developed a detailed system of national time accounting. This includes both market and nonmarket uses of time, combined with evaluations based on measures of subjective well-being. ${ }^{67}$

A comprehensive review of nonmarket accounts is provided by Kath-

66. See the following for data from the World Bank: http://web.worldbank.org/WBSITE /EXTERNAL/TOPICS/EXTPOVERTY/EXTPA/0, contentMDK:20202198 menuPK :435055 pagePK:148956 piPK:216618 theSitePK:430367,00.html.

For data from the Luxembourg Income Study, see http://www.lisdatacenter.org/.

67. See Krueger (2009). 
arine B. Abraham and Christopher Mackie $(2005,2006)$ and their coauthors. ${ }^{68}$ This includes accounts for household production, investments in education and health, activities of nonprofit organizations and governments, and environmental assets and services. Erwin Diewert and Paul Schreyer (chapter 4, this volume) provide a model of household production and consumption and an international comparison.$^{69}$ Michael B. Christian (chapter 14, this volume) presents human capital accounts for the United States, and Gang Liu (chapter 15, this volume) presents these accounts for sixteen countries, including fifteen OECD members. ${ }^{70}$ Nicholas Muller, Robert Mendelsohn, and William Nordhaus (2011) have constructed a system of environmental accounts for the United States. ${ }^{71}$ Allison B. Rosen and David M. Cutler (2007) have proposed a system of national health accounts for the United States. ${ }^{72}$

Jorgenson and Slesnick (2008) have extended the model of consumer behavior presented in the appendix to include the demand for leisure, as well as goods and services. ${ }^{73}$ This concept of leisure includes the nonmarket time used for household production, investments in education and health, and volunteer activities. Leisure time based on the CEX could be included in measures of individual and social welfare like those we have presented for market goods and services.

The next step in integrating the NIPAs with the Flow of Funds Accounts will be to extend the national balance sheet for the US economy. The prototype system of national accounts generated by Jorgenson, Landefeld, and Nordhaus (2006) could incorporate balance sheets for the individual sectors identified in the Flow of Funds Accounts. This could be used as the basis of intertemporal measures of individual and social welfare. For this purpose a representation of consumer behavior like that employed by Jorgenson and Slesnick (2008) would be required.

\section{Appendix}

\section{Modeling Consumer Behavior}

The system of individual expenditure shares (6) can be fitted without requiring that it is generated from an indirect utility function of the form (4). We

68. Abraham and Mackie (2005). A summary is provided by Abraham and Mackie in Jorgenson, Landefeld, and Nordhaus, eds. (2006, 161-92). The conceptual basis for nonmarket accounting is discussed by Nordhaus in Jorgenson, Landefeld, and Nordhaus (2006, 143-60). Abraham (chapter 2, this volume) presents a survey of expanded measures of welfare.

69. Diewert and Schreyer (2013).

70. Christian (chapter 14, this volume) and Liu (chapter 15, this volume).

71. Muller, Mendelsohn, and Nordhaus (2011). Additional results are given by Muller (chapter 13 , this volume).

72. Rosen and Cutler (2007).

73. Jorgenson and Slesnick (2008). 
say that the system is integrable if it can be generated from such an indirect utility function. Since we utilize the indirect utility functions for all consuming units in measuring social welfare, we impose conditions for integrability on the individual demand functions. A complete set of conditions for integrability ${ }^{74}$ is the following:

Homogeneity. The individual expenditure shares are homogeneous of degree zero in prices and total expenditure.

We can write the individual expenditure shares in the form

$$
w_{k}=\frac{1}{D(p)}\left(\alpha_{p}+B_{p p} \ln p-\beta_{p M} \ln M_{k}+B_{p A} A_{k}\right),(k=1,2, \ldots, K),
$$

where the vector of parameters $\beta_{p M}$ is constant and the same for all consumer units. Homogeneity implies that this vector must satisfy the restrictions

$$
\beta_{p M}=B_{p p} i .
$$

Given the exact aggregation restrictions, there are $N-1$ restrictions implied by homogeneity.

Summability. The sum of the individual expenditure shares over all commodity groups is equal to unity

$$
i^{\prime} w_{k}=1,(k=1,2, \ldots, K) .
$$

We can write the denominator $D(p)$ in (1.3.5) in the form

$$
D=-1+\beta_{M p} \ln p,
$$

where the vector of parameters $\beta_{M p}$, is constant and the same for all commodity groups and all consuming units. Summability implies that this vector must satisfy the restrictions

$$
\beta_{M p}=i^{\prime} B_{p p} .
$$

Given the exact aggregation restrictions, there are $N-1$ restrictions implied by summability.

Symmetry. The matrix of compensated own- and cross-price substitution effects must be symmetric.

If the system of individual expenditure shares can be generated from an indirect utility function of the form (4), a necessary and sufficient condition for symmetry is that the matrix $B_{p p}$ must be symmetric. Without imposing this condition, we can write the individual expenditure shares in the form:

$$
w_{k}=\frac{1}{D(p)}\left(\alpha_{p}+B_{p p} \ln \frac{p}{M_{k}}+B_{p A} A_{k}\right),(k=1,2, \ldots, K) .
$$

74. This set of conditions is based on the classic formulation of the theory of consumer behavior by Chipman et al. (1971). Details are presented by Jorgenson, Lau, and Stoker (1982, 287-301). 
Symmetry implies that the matrix of parameters $B_{p p}$ must satisfy the restrictions:

$$
B_{p p}=B_{p p}^{\prime} .
$$

The total number of symmetry restrictions is $(1 / 2) N(N-1)$.

Nonnegativity. The individual expenditure shares must be nonnegative. By summability the individual expenditure shares sum to unity, so that we can write:

$$
w_{k} \geq 0,(k=1,2, \ldots, K),
$$

where $w_{k} \geq 0$ implies $w_{n k} \geq 0(n=1,2, \ldots, N)$, and $w_{k} \neq 0$.

Since the translog indirect utility function is quadratic in the logarithms of prices, we can always choose the prices so that the individual expenditure shares violate the nonnegativity conditions. Accordingly, we cannot impose restrictions on the parameters of the translog indirect utility functions that would imply nonnegativity of the individual expenditure shares for all prices and total expenditure. Instead we consider restrictions on the parameters that imply monotonicity of the system of individual demand functions for all data points in our sample.

Monotonicity. The matrix of compensated own- and cross-price substitution effects must be nonpositive definite.

We introduce the definition, due to Martos (1969), of a strictly merely positive subdefinite matrix; namely, a real symmetric matrix $S$ such that:

$$
x^{\prime} S x<0
$$

implies $S x>0$ or $S x<0 .{ }^{75}$ A necessary and sufficient condition for monotonicity is either that the translog indirect utility function is homothetic or that $B_{p p}^{-1}$ exists and is strictly merely positive subdefinite.

In implementing the econometric model of consumer behavior we divide consumer expenditures among five commodity groups. These groups are aggregates defined on a much more detailed classification of commodities, as described by Jorgenson, Slesnick, and Stoker (1987) ${ }^{76}$ We assume that the indirect utility functions are homothetically separable in prices of the commodities within each group:

1. Energy: expenditures on electricity, natural gas, heating oil, and gasoline

2. Food: expenditures on all food products, including tobacco and alcohol

3. Consumer goods: expenditures on all other nondurable goods

4. Capital services: the service flow from consumer durables and housing

5. Consumer services: expenditures on consumer services, such as car repairs, medical services, entertainment, and so on 
We employ the following demographic characteristics as attributes of individual households:

1. Family size: 1, 2, 3, 4, 5, 6, and 7 or more persons

2. Age of head of household: 16-24, 25-34, 35-44, 45-54, 55-64, 65 and over

3. Region of residence: Northeast, North-Central, South, and West

4. Race: white, nonwhite

5. Type of residence: urban, rural

6. Gender of head of household: male, female

We treat expenditure shares for the five commodity groups as endogenous variables, so that we estimate four equations. As unknown parameters we have four elements of the vector $\alpha_{p}$, four expenditure coefficients of the vector $B_{p p} i$, seventeen attribute coefficients for each of the four equations in the matrix $B_{p A}$, and ten price coefficients in the matrix $B_{p p}$ which is constrained to be symmetric. The expenditure coefficients are sums of price coefficients in the corresponding equation, so that we have a total of eighty-six unknown parameters. Jorgenson and Slesnick (1987) estimated the complete model by pooling time-series and cross-section data. This model was revised to include gender of head of household and updated by Slesnick (2001). Our cross-section observations on consumption expenditures for each commodity group and demographic characteristics of individual households are from the Survey of Consumer Expenditures (CEX). ${ }^{77}$

\section{References}

Abraham, Katharine G., and Christopher Mackie, eds. 2005. Beyond the Market: Designing Nonmarket Accounts for the United States. Washington, DC: National Academies Press.

_. 2006. "A Framework for Nonmarket Accounting." In A New Architecture for the US National Accounts, edited by Dale W. Jorgenson, J. Steven Landefeld, and William D. Nordhaus, Studies in Income and Wealth 66:161-92. Chicago: University of Chicago Press.

Advisory Committee on Measuring Innovation in the Twenty-First Century Economy. 2008. Innovation Measurement: Tracking the State of Innovation in the 21st Century Economy. Washington, DC: Department of Commerce. January.

Atkinson, Anthony B. 1970. "On the Measurement of Inequality." Journal of Economic Theory 2 (3): 244-63.

Attanasio, Orazio, Erik Hurst, and Luigi Pistaferri. 2012. "The Evolution of Income, Consumption, and Leisure Inequality in the U.S., 1980-2010.” NBER Working Paper no. 17982, Cambridge, MA.

77. Our measures of personal consumption expenditures and consumption at the microeconomic level are discussed in detail by Slesnick (2001, 47-66) and Jorgenson and Slesnick (2008). 
Barten, Anton P. 1964. "Family Composition, Prices, and Expenditure Patterns." In Econometric Analysis for Economic Planning: 16th Symposium of the Colston Society, edited by Peter Hart, Gareth Mills, and John D. Whitaker, 277-92. London: Butterworth.

Becker, Gary S. 1981. A Treatise on the Family. Cambridge, MA: Harvard University Press.

Chen, Shaohua, and Martin Ravallion. 2010. "The Developing World is Poorer than We Thought, but No Less Successful in the Fight Against Poverty." Quarterly Journal of Economics 125 (4): 1577-629.

Chipman, John S., Leonid Hurwicz, Marcel K. Richter, and Hugo F. Sonnenschein, eds. 1971. Preferences, Utility, and Demand. New York: Harcourt, Brace, Jovanovich.

Chipman, John S., and James C. Moore. 1973. "Aggregate Demand, Real National Income, and the Compensation Principle." International Economic Review 14 (1): $153-81$.

1980. "Real National Income with Homothetic Preferences and a Fixed Distribution of Income." Econometrica 48 (2): 401-22.

Citro, Constance, and Robert Michael, eds. 1995. Measuring Poverty: A New Approach. Washington, DC: National Academies Press.

Dalton, Hugh. 1920. "The Measurement of the Inequality of Income." Economic Journal 30 (119): 361-84.

Deaton, Angus. 2010. "Price Indexes, Inequality, and the Measurement of World Poverty." American Economic Review 100 (1): 5-34.

Deaton, Angus, and John Muellbauer. 1980. Economics and Consumer Behavior. Cambridge: Cambridge University Press.

Fesseau, Maryse, and Maria Liviana Mattonetti. Forthcoming. "Distributional Measures among Household Groups in a National Accounts Framework: Results from an Experimental Cross-Country Exercise on Household Income, Consumption, and Saving." OECD Statistics Working Paper no. 2013/4, Organisation for Economic Co-operation and Development, Paris.

Fesseau, Maryse, Florence Wolff, and Maria Liviana Mattonetti. Forthcoming. "A Cross-Country Comparison of Household Income, Consumption and Wealth between Micro Sources and National Accounts Aggregates." OECD Statistics Working Paper no. 2013/3, Organisation for Economic Co-operation and Development, Paris.

Fisher, Jonathan, David Johnson, and Timothy Smeeding. 2012. "Inequality of Income and Consumption: Measuring the Trends in Inequality from 1985-2010 for the Same Individuals." Thirty-Second General Conference, International Association for Research in Income and Wealth, Boston, Massachusetts, August, pp. 6-9.

Fleurbaey, Marc. 2009. "Beyond the GDP: The Quest for Measures of Social Welfare." Journal of Economic Literature 47 (4): 1029-75.

Fleurbaey, Marc, and Peter J. Hammond. 2004. "Interpersonally Comparable Utility." In Handbook of Utility Theory: Extensions, edited by Salvador Barbera, Peter J. Hammond, and Christian Seidl, 1179-285. Heidelberg: Springer.

Fleurbaey, Marc, and Francois Maniquet. 2011. A Theory of Fairness and Social Welfare. Cambridge: Cambridge University Press.

Gorman, William M. 1953. "Community Preference Fields." Econometrica 21 (1): 63-80.

Hammond, Peter J. 1977. "Dual Interpersonal Comparisons of Utility and the Economics of Income Distribution." Journal of Public Economics 7 (1): 51-71.

. 1978. "Economic Welfare with Rank Order Price Weighting." Review of Economic Studies 45 (2): 381-4. 
Harper, Michael, Brent Moulton, Steven Rosenthal, and David Wasshausen. 2009. "Integrated GDP-Productivity Accounts." American Economic Review 99 (2): 74-9.

Hicks, John R. 1940. "The Valuation of Social Income." Economica N.S. 7:105-24. Jorgenson, Dale W. 1966. "The Embodiment Hypothesis." Journal of Political Economy 74 (1): 1-17.

. 1990. "Aggregate Consumer Behavior and the Measurement of Social Welfare." Econometrica 58 (5): 1007-40.

1997a. Aggregate Consumer Behavior. Cambridge, MA: The MIT Press.

1997b. Measuring Social Welfare. Cambridge, MA: The MIT Press.

2001. "Information Technology and the US Economy." American Economic Review 91 (1): 1-32.

- 2009. "A New Architecture for the US National Accounts." Review of Income and Wealth 55 (1): 1-42.

- 2011. "Innovation and Productivity Growth: T. W. Schultz Lecture." American Journal of Agricultural Economics 93 (2): 276-96.

- 2012. "The World KLEMS Initiative." International Productivity Monitor 24 (Fall): 5-19.

Jorgenson, Dale W., Mun S. Ho, and Samuels. 2012. "A Prototype Industry-Level Production Account for the United States, 1947-2010." Presented to the Final Conference of the World Input-Output Database project, Groningen, The Netherlands, April 25. http://www.economics.harvard.edu/faculty/jorgenson/files/12 _0425_WIOD.pdf.

Jorgenson, Dale W., Mun S. Ho, and Kevin J. Stiroh. 2008. "A Retrospective Look at the US Productivity Growth Resurgence.” Journal of Economic Perspectives 22 (1): $3-24$.

Jorgenson, Dale W., J. Steven Landefeld, and William D. Nordhaus, eds. 2006. $A$ New Architecture for the US National Accounts, Studies in Income and Wealth, vol. 66. Chicago: University of Chicago Press.

Jorgenson, Dale W., Lawrence J. Lau, and Thomas M. Stoker. 1982. "The Transcendental Logarithmic Model of Aggregate Consumer Behavior." In Advances in Econometrics, vol. 1, edited by Robert L. Basmann and George Rhodes, 97-238. Greenwich, CT: JAI Press.

Jorgenson, Dale W., and Paul Schreyer. 2013. "Industry-Level Productivity Measurement and the 2008 System of National Accounts." Review of Income and Wealth 59 (2): 185-211.

Jorgenson, Dale W., and Daniel T. Slesnick. 1983. "Individual and Social Cost-ofLiving Indexes." In Price Level Measurement, edited by W. Erwin Diewert and Claude Montmarquette, 241-323. Ottawa: Statistics Canada.

Jorgenson, Dale W., and Daniel T. Slesnick. 1984. "Aggregate Consumer Behavior and the Measurement of Inequality." Review of Economic Studies 51 (3): 369-91.

Jorgenson, Dale W., and Daniel T. Slesnick. 1987. "Aggregate Consumer Behavior and Household Equivalence Scales." Journal of Business and Economic Statistics 5 (2): 219-32.

Jorgenson, Dale W., and Daniel T. Slesnick. 1990. "Inequality and the Standard of Living." Journal of Econometrics 43 (1-2): 103-20.

Jorgenson, Dale W., and Daniel T. Slesnick. 2008. "Consumption and Labor Supply." Journal of Econometrics 127 (1): 326-35.

Jorgenson, Dale W., Daniel T. Slesnick, and Thomas M. Stoker. 1987. "Two-Stage Budgeting and the Consumer Demand for Energy." In Advances in the Economics of Energy and Resources, vol. 6, edited by John R. Moroney, 125-62. Greenwich, CT: JAI Press. 
Kolm, Serge C. 1969. "The Optimal Production of Social Justice." In Public Economics, edited by Julius Margolis and Henri Guitton, 145-200. London: Macmillan.

Krueger, Alan B. 2009. Measuring the Subjective Well-Being of Nations: National Accounts of Time Use and Well-Being. Chicago: University of Chicago Press.

Landefeld, J. Steven, Brent Moulton, Joel D. Platt, and Shaunda M. Villones. 2010. "GDP and Beyond: Measuring Economic Progress and Sustainability." Survey of Current Business 90 (4): 12-25.

Lewbel, Arthur. 1989. "Household Equivalence Scales and Welfare Comparisons." Journal of Public Economics 39 (3): 377-91.

Martos, Bela. 1969. "Subdefinite Matrices and Quadratic Forms." SIAM Journal of Applied Mathematics 17 (6): 1215-23.

Mas, Matilde, and Robert Stehrer, eds. 2012. Industrial Productivity in Europe: Growth and Crisis. Cheltenham, UK: Edward Elgar.

McKenzie, Lionel W. 1957. "Demand Theory without a Utility Index." Review of Economic Studies 24 (65): 185-9.

Meyer, Bruce, and James Sullivan. 2009. "Five Decades of Consumption and Income Poverty.” NBER Working Paper no. 14827, Cambridge, MA.

Muellbauer, John. 1976. "Community Preferences and the Representative Consumer." Econometrica 44 (5): 979-99.

Muller, Nicholas, Robert Mendelsohn, and William Nordhaus. 2011. "Environmental Accounting for Pollution in the United States." American Economic Review 100 (3): 1649-75.

Nordhaus, William D., and James Tobin. 1973. "Is Growth Obsolete?" In The Measurement of Economic and Social Performance, edited by Milton Moss, 509-64. Princeton, NJ: Princeton University Press.

Organisation for Economic Co-operation and Development. 2013a. Framework for Statistics on the Distribution of Household Income, Consumption, and Wealth. Paris: OECD.

. 2013b. Guidelines for Micro Statistics on Household Wealth. Paris: OECD.

Pollak, Robert A. 1981. "The Social Cost of Living Index." Journal of Public Economics 15 (3): 311-36.

Ravallion. 2012. "More Relatively-Poor People in a Less Absolutely-Poor World." Nancy and Richard Ruggles Memorial Lecture, International Association for Research in Income and Wealth, Boston, Massachusetts, August.

Roberts, Kevin W. S. 1980. "Possibility Theorems with Interpersonally Comparable Welfare Levels." Review of Economic Studies 47 (147): 409-20.

Rosen, Allison B., and David M. Cutler. 2007. "Measuring Medical Care Productivity: A Proposal for US National Health Accounts.” Survey of Current Business 87 (6): 54-8.

Roy, Rene. 1943. De l'Utilité. Contribution à la Théorie des Choix. Paris: Hermann \& Cie.

Samuelson, Paul A. 1950. "Evaluation of Real National Income." Oxford Economic Papers N.S. 1:1-29. $1-22$.

1961. "The Evaluation of 'Social Income.'” In The Theory of Capital, edited by F. A. Lutz and D. C. Hague, 32-57. London: Macmillan.

Schreyer, Paul. 2001. Measuring Productivity. Paris: Organisation for Economic Cooperation and Development.

. 2009. Measuring Capital. Paris: Organisation for Economic Co-operation and Development. 
Sen, Amartya K. 1970. Collective Choice and Social Welfare. San Francisco: HoldenDay.

1976. "Real National Income.” Review of Economic Studies 43 (133): 19-40. 1979. "The Welfare Basis for Real Income Comparisons: A Survey.” Journal of Economic Literature 17 (1): 1-45.

Slesnick, Daniel T. 1994. "Consumption, Needs, and Inequality." International Economic Review 35 (3): 677-703.

1998. "Empirical Approaches to the Measurement of Welfare." Journal of Economic Literature 36 (4): 2108-65.

- 2001. Consumption and Social Welfare: Living Standards and Their Distribution in the United States. Cambridge: Cambridge University Press.

Stiglitz, Joseph E., Amartya Sen, and Jean-Paul Fitoussi. 2010. Mismeasuring Our Lives: Why GDP Doesn't Add Up. New York: The New Press.

Teplin, Albert M., Rochelle Antoniewicz, Susan Hume McIntosh, Michael Palumbo, Genevieve Solomon, Charles Ian Mead, Karin Moses, and Brent Moulton. 2006. "Integrated Macroeconomic Accounts for the United States: Draft SNA-USA." In A New Architecture for the US National Accounts, Studies in Income and Wealth, vol. 66, edited by Dale W. Jorgenson, J. Steven Landefeld, and William D. Nordhaus, 471-540. Chicago: University of Chicago Press.

Timmer, Marcel P., Robert Inklaar, Mary O'Mahony, and Bart van Ark. 2010. Economic Growth in Europe: A Comparative Industry Perspective. Cambridge: Cambridge University Press.

United Nations. 2009.2008 System of National Accounts. New York: United Nations. http://unstats.un.org/unsd/nationalaccount/sna2008.asp.

Weitzman, Martin. 1976. "On the Welfare Significance of National Product in a Dynamic Economy." Quarterly Journal of Economics 90 (1): 156-62.

. 2003. Income, Wealth, and the Maximum Principle. Cambridge, MA: Harvard University Press.

World Bank. 2008. Global Purchasing Power Parities and Real Expenditures: 2005 International Comparison Program. Washington, DC: World Bank. http://site resources.worldbank.org/ICPEXT/Resources/ICP_2011.html. 